\title{
Testing Russia's Virtual Economy
}

\author{
By: Vlad Ivanenko
}

William Davidson Working Paper Number 428

December 2001 


\title{
Testing Russia's Virtual Economy
}

By Vlad Ivanenko

December 2001

\begin{abstract}
In the aftermath of sovereign default of August 1998, the hypothesis of virtual economy in Russia developed by Gaddy and Ickes has gained popularity. The hypothesis states that the country has not moved towards free-market economy but developed a system of implicit price subsidization similar to what had existed before. Non-viable sectors that the state supported with subsidies before survive by over-pricing their output. Customers pass the bill back to the government by reducing their tax liabilities.

We test the proposition that the distribution of the value-added across sectors is biased because of price distortions and estimate the distribution at world prices. The results support the claim that Russian price structure is different from the world level and three out of fifteen sectors, for which we construct price indices, become "value-destroying". We investigate the reasons behind price differentials and find that difference in processing and the use of barter explain a large part of it.
\end{abstract}

JEL code: P2, P3, P52

Keywords: Russia, virtual economy, effective value-added

\footnotetext{
${ }^{1}$ Dept. of Economics, University of Western Ontario, London, Ontario N6A 5C2, Canada, e-mail <vivanenk@uwo.ca>. The author is grateful to Knick Harley, Kul Bhatia, Jim Davies, and participants of a seminar at the University of Western Ontario (London, Canada). Konstantin Loukine of the Department of Foreign Affairs and International Trade (Ottawa) has provided valuable comments on the earlier drafts. Vera Ivanenko has done her best upholding grammatical principles. The remaining errors and omissions are the sole author's responsibility.
} 


\section{William Davidson Institute Working Paper 428}

\section{Non-Technical Summary}

In early 1998 Gaddy and Ickes suggested a new idea explaining why the Russian transition apparently failed. Managers of economically bankrupt companies have preserved price distortions inherited from the Soviet time by exploiting political connections that they had developed during the time of command economy. They overcharged customers in barter transactions and created the pretense that the firms are economically viable. In their turn, the customers accepted "bad" deals because they have reduced nominal barter prices to market levels by employing offsets and accumulating arrears. The bill has been ultimately passed to the government through tax offsets. The latter is reluctant to expose the pretense because otherwise, it faces mass unemployment and subsequent political instability.

Following this logic, Gaddy and Ickes have inferred that the emphasis on preserving the nominal value of GDP in transition is wrong. If authorities press for settlement in money, the non-productive nature of many companies becomes obvious. Gaddy and Ickes have predicted that when it happens, the Russian economy contracts in the short run in absolute numbers but positions itself for the long-term growth by freeing resources that the value-destroying companies wasted before.

The default that happened in August 1998 seemingly justified their point of view. As the market exchange rate soared from 5,974 to 21,140 Rubles to the US Dollar, the dollar estimate of the Russian GDP fell from \$414,897 million in 1997 to \$127,548 million in 1998. The notion that Russia had developed a peculiar form of "virtual economy" gained prominence.

The theory that Gaddy and Ickes proposed fitted nicely in the general perception of the Russian reform that emerged in the West following the default. It is hard to find publications of that time not peppered with accusations of bureaucratic corruption, theft of state assets, and pocketing of Western loans. This atmosphere affected policy-making with hardliners pushing for "tough love" with Russia and preaching that the country was a wreck and irrelevant anymore.

Yet, after gloomy predictions of impeding collapse in Russia failed to materialize, the voice of dissenters became heard. Joseph Stiglitz, the Chief Economist at the World Bank and a fierce critic of the policy of the Washington Consensus, ${ }_{\text {was }}$ the first to suggest that it might be we who are wrong and not they. He compared two transitions - Chinese and Russian - and asked the question of why the Chinese did opposite to what we advised and succeeded while the Russians followed the advice and failed? His answer was that assuming market institutions appear if government steps down is naive. Stiglitz did not question the importance of markets in itself but pondered on what form they might assume in transition. Judging by the Chinese experience, he decided that endogenously developed stakeholders' arrangements

\footnotetext{
${ }^{2}$ See Gaddy and Ickes [1998a and 1998b], Gaddy and Ickes [1999], and Ickes and Ericson [2000]

${ }^{3}$ At the end of December exchange rate at the Moscow International Currency Exchange, in non-denominated rubles. Data on GDP are from GKS [2000b] and on the exchange rate are from the Stockholm Institute of Transition Economics and East European Economies, "Russian Economic Trends Database", Stockholm 2000, available at http://www.hhs.se/site/ret/ret.htm.

${ }^{4}$ The Washington Consensus is a set of "sound" economic policies, which international and national economic organizations based in Washington agreed upon in the late 80-s. See John Williamson "What Washington Means by Policy Reform”, in Latin American Adjustment: How Much Has Happened?, pp. 5-20, ed. John Williamson, Institute for International Economics, Washington, DC, April 1990, for details.
} 


\section{William Davidson Institute Working Paper 428}

are superior to the Western-style shareholders' privatization plans in the absence of Western social norms.

This clash of policy approaches has not generated quick empirical response. In part, empirical research has lagged behind because of data constraints but the instability of public opinion played a role as well. In the case of the virtual economy, as the initial interest in the hypothesis faded away, it was virtually forgotten. The only exchange of opinions with reference to facts, that the author is aware of, took place in October 1998 in the website

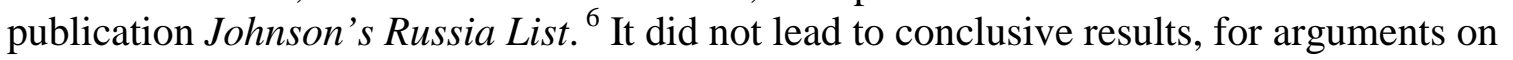
both sides were based on anecdotal evidence. For example, the four-sector model of Gaddy and Ickes [1998b] introduces notation explicitly referring to Norilsk Nickel and Norilsk Gazprom. While both companies are large and important (Norilsk Nickel was the largest privately-owned company ranked by assets in 1997), their relationship is unrepresentative. Opponents of the hypothesis seized the unfortunate case of gas-for-metal payment scheme to bring counter-examples of large foundries that used different arrangements. This focus on specific companies was unconvincing to both sides. However, as time passes, more evidence becomes available enabling us to contribute to the discussion on the role of barter and arrears in the Russian transition.

In this paper, we test the validity of the hypothesis of the virtual economy. The paper consists of four sections. Section 1 sketches the hypothesis and considers its predictions that we check afterwards. We do not expose the hypothesis in full because some parts are not addressed in the present investigation and other parts were not fully developed by its authors. It is sufficient for our purposes to concentrate attention on the key elements.

Section 2 explains how the statement that barter and arrears distort price signals and facilitate the survival of non-viable companies can be tested. We explore methodologies that are used in determining prices of goods produced by natural monopolies or imported from non-market economies. The literature on the measurement of value-added transferred resulting from tariff barriers is considered. A short discussion on data requirements concludes the section.

Section 3 is the core of the paper. It tests the proposition that Russian prices are not representative of actual values of the traded goods. We supplement domestic prices with prices attained in a market economy and find what the value-added for sectors would be in such circumstances. The result is that twelve out of fifteen sectors generate positive valueadded. The sectors that become 'value-destroying' on price conversion belong to the lowprocessing segment of manufacture. This finding is at odds with the concept of the virtual economy that expects sectors with high degree of processing to be the least productive.

Section 4 introduces several reasons why Russian and world prices differ and checks their validity. We consider the degree of processing, the share of barter and change in trade arrears, effective import tariffs, and price inertia as the explanatory factors. The obtained results point out that the degree of processing and barter explain a large part of the difference. Russian

\footnotetext{
${ }^{5}$ An interested reader is referred to Stiglitz, Joseph E. "Whither Reform? Ten Years of the Transition". Keynote address at the ABCDE, World Bank, Washington, DC, April 1999 (was available at http://www.worldbank.org/research/abcde/stiglitz.html). By the stakeholders' arrangement, we mean the organizational structure where powerful insiders own the firm while they are employed and have to abrogate their rights otherwise.

${ }^{6}$ See Johnson's Russia List (JRL) issues 2413, 2416, 2420, 2422, and 2424 for October 6-11, 1998 available at http://www.cdi.org/. JRL is an informal but influential forum that brings together scholars, journalists, government officers, and public working with Russian issues. The list is run by David Johnson accessible at davidjohnson@erols.com

${ }^{7}$ These two companies are in monopsony-monopoly relationship and all imperfections associated with such a market are present.
} 


\section{William Davidson Institute Working Paper 428}

prices are found to be correlated with pre-transition levels and they are converging to the world level at the same time.

The paper concludes with several appendices. Appendix A presents statistical data on the share of barter and arrears in Russia. This topic is relevant to the discussion because nonmonetary exchanges play a key role in the hypothesis and we say few words about it in Section 1. The other appendices provide technical details. We explain the methodology of how sectoral price ratios reported in Section 3 are found and present conversion tables for 232 sampled goods in Appendix B. Appendix C deals with the problem of tariff protection rates that are used to address the question of domestic-world price differentials raised in Section 3. Appendix D explains the methodology of calculating the index of processing that we use in Section 4. 


\section{The Relevance of Non-Monetary Exchanges to the Virtual Economy}

When Gaddy and Ickes proposed the hypothesis of the virtual economy first, they observed bits and pieces of the economic environment that was complex and not described systematically. They detected unusual modes of trade and proposed an unorthodox explanation for this phenomenon. 1

The essence of Gaddy and Ickes's story can be summarized in the following quotation: “At (the) heart (of the virtual economy) is the ultimate pretense that the Russian economy is larger than it really is. ... It is the cause of the web of non-payments ... from which Russia seemingly cannot emerge. ... (T)his story ... is a familiar one: The enterprises don't pay their suppliers; they don't pay their workers; they don't pay their taxes." By non-payment Gaddy and Ickes mean that the agents engage in non-monetary exchanges.

We do not attempt to present all arguments and to explain the model that Gaddy and Ickes develop in detail. There is sufficient literature, to which an interested reader is referred. $^{-1}$ Besides, going into details tends to distract attention. The phenomenon of non-monetary exchanges in Russian transition offers a large number of competing explanations all of them suffering from small inconsistencies. To avoid being drawn into an open-ended discussion of why and how Russia developed trade without money, we focus our attention on two particular features. The first is the notion that prices for bartered and provided in credit goods and services were not of market origin and the second is the suggestion that processing sectors benefited from the non-monetary exchanges.

The hypothesis, that Gaddy and Ickes propose, introduces a two-sector economy producing primary and processed goods. For the sake of illustration let them be oil and machinery. Both goods serve as inputs in the production of one another. Government distorts the market by allowing firms to offset taxes with the delivery of machinery. The demand for machinery grows since taxpayers use them to minimize their tax obligations. The minimization works through barter schemes. If machinery is bartered for oil, it is optimal for both sides to inflate prices. Taxes are paid in nominal terms and, if the barter price for machinery is higher, it covers more of tax liabilities. Then, oil producers can exchange less of oil for machinery delivered later to the government than selling the same amount for money paid in taxes. Machinery producers are happy because they get relatively more oil in barter deals than when they pay in money.

If the government demands paying taxes in money, oil producers stop buying machinery for tax purposes. The reason for barter exchanges disappears and relative prices change. This new situation changes the structure of costs and revenue and machinery producers find that the cost of oil that they use in production exceeds the value of machines.

This logic suggests the structure of our first test. If we know the structure of costs and revenue and if we are able to obtain estimates of market prices with no distortions, we can check the

\footnotetext{
${ }^{1}$ In general, it is not obvious that barter and arrears are of non-market nature, for both modes are legitimate in market economies. Apparently, the degree of non-monetary exchanges struck observers as unusual.

${ }^{2}$ See Gaddy and Ickes [1998c]

${ }^{3}$ Apparently, the model continues to be refined: As recently as November 7, 2001 Gaddy was introduced as a coauthor of a forthcoming book Russia's Virtual Economy. During the briefing he confirmed that the idea of virtual economy is very much alive (see Brookings Briefing "President Putin Comes to America: Is An Old Adversary Becoming a New Partner?” at www.brookings.edu).

${ }^{4}$ Gaddy and Ickes [1998a, 1998b, 1998c, 1999]
} 
proposition that the barter hides the inter-sectoral transfer of value. The first problem that we encounter is to find "good" prices that we assume are unobservable at the actual market place according to the hypothesis of virtual economy.

\section{Prices in the Absence of Markets: Methodological Issues}

Economists have devised several methods to derive shadow prices for non-marketable goods. Pricing the output of natural monopolies is one example. By definition, a natural monopoly market is distorted in the sense that the allocation of resources is inefficient.

Responding to economic inefficiency that monopolistic pricing introduces, the government corrects the situation by setting a price range. The problem that the government faces is apparently similar to what we have: "good" prices are unobservable and are to be inferred.

The general solution to the problem of monopolistic pricing is to calculate the average cost of production for a number of companies, add a markup, and come to the unit price. This method is unsuited for our purposes. Essentially, it is based on the assumption that, while output prices are distorted, the input prices are not. We cannot make this assumption because the hypothesis of virtual economy conjectures that the values of both outputs and inputs are set outside of the market.

The second method originates in the international trade practice. The General Agreement on Trade and Tariffs (GATT) acknowledges the possibility of "dumping" and legitimizes the use of

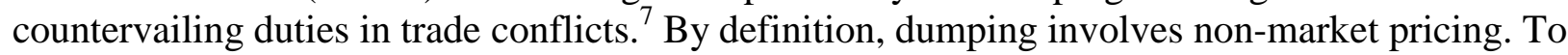
bring the announced price back to its market level, the trade authority of a country affected levies a duty that covers the difference.

The situation of dumping corresponds to what Gaddy and Ickes allege Russia faced in 1997 in reverse: announced prices were higher than what would be efficient. This similarity of situations suggests that we are able to use international trade practices to construct a methodology of finding market values for Russian goods. Unfortunately, this approach applies to tradable goods only.

Let us consider in detail how the value of countervailing duties is calculated in practice. The trade authority can use the same cost pricing approach as in the case of natural monopoly. It takes the average price at which the imported good is sold domestically in the exporting country, and finds the difference between exported and domestic price determining the duty. Again, this method is based on the assumption that domestic prices are efficient, which contradicts to the setting of the hypothesis we consider.

If an imported good is deemed to be valued outside of the market of the exporting country, its price structure is totally discounted and replaced with the prices determined in an "analogue

\footnotetext{
${ }^{5}$ In limit, the range collapses to a single price.

${ }^{6}$ For example, we can use averaged cost structure for a group of utility providers of adjacent provinces or states.

${ }^{7}$ See GATT [1986, Article VI].
} 
country". This approach uses the same assumptions as we do and is taken as the basis for our methodology. The problem of the analogue country comes next.

The concept of the analogue country is not well specified in trade documents and the World Trade Organization does not mention it on its website. The European Union is explicit about the concept. Article 2(7) of the Council Regulation (EC) No 384/96 of 22 December 1995 states that "In the case of imports from non-market economy countries ... normal value shall be determined on the basis of the price ... in a market economy third country". The EU fails to set explicit criteria for determining how the analogue country is to be selected noting only that the analogue country "shall be selected in a not unreasonable manner,due account being taken of any reliable information made available at the time of selection". 10 Further examination of legal documents related to countervailing duties imposed by the EU has shown that it uses the following criteria selecting the analogue country:

- a country has been used previously in a similar investigation

- a country cooperates in the investigation

- $\quad$ it has several producers leading to strong domestic competition

- the price of the product in this country is similar to that in the EU and the costs of inputs is similar to the cost structure of the exporting country

Taken together, these requirements impose severe limits on the list of potential candidates and the effort by the EU to make the full use of the clause on "not unreasonable choice" is perfectly understandable. 12

We propose to use the US as the analogue country. This country produces a wide variety of goods and is similar in geographic size and the wealth of natural resources to Russia. This country is often taken for two-country comparative studies. The US economic data is readily available. Finally, America is believed to have the freest market in the world and its prices arguably reflect the most efficient allocation of resources, the condition that we attempt to find.

\footnotetext{
${ }^{8}$ In addition, Russia is explicitly considered to have a non-market economy in several trade disputes. See the Council Regulation (EC) No 519/94 of 7 March 1994 on common rules for imports from certain third countries (available at http://www.iue.it/LAW/globalisation/documenti/ecreg_519_94.htm).

${ }^{9}$ The author has been advised that the US Trade Commission used a similar approach in 1980s.

${ }^{10}$ See the Council Regulation (EC) No 384/96 of 22 December 1995 on protection against dumped imports from countries not members of the European Community (available at http://www.iue.it/LAW/globalisation/documenti/ecreg_384_96.htm).

${ }^{11}$ The EU website (http://europa.eu.int/eur-lex/en/lif/reg/en_register_11604020.html) lists the directory of Community anti-dumping rulings. It contains around 100 regulations, out of which ten relates to Russia. We have used Council Regulation (EC) No 1100/2000 of 22 May 2000 and No 1995/2000 to compile a list of requirements regarding the choice of the analogue country.

${ }^{12}$ For example, in the anti-dumping case referring to the import of urea from Russia, the EU committee recommended to use the cost structure provided by the only producer in Slovakia as the benchmark against which the costs of Russian urea manufacturers were recalculated. The proposal of EU importers to use Canadian data on the ground that Slovakia does not extract gas (a major component in urea production) was rejected because Canada did not answer on the lengthy questionnaire sent during the hearings. Brazil appears the most often as a candidate but the author has not been able to find consistent data from this country.

${ }^{13}$ If geographic proximity would be the most definite factor, Germany is a better candidate. The author has been advised that German data are well detailed for comparative purposes than American's but America appears to be
} 
The experiment that we conduct in this paper differs from regular trade practice of assessing the countervailing duty in one important aspect. Unlike considering a single product, against which a complaint is lodged, efficient prices for a wide array of products are to be found while accounting for secondary effects introduced by technological constraints. The latter is introduced through the use of input-output table.

In this study, we face serious data limitations. The Russian State Committee for Statistics (GKS) does not publish much data and what is published is distributed through its commercial branch that limits further access. There are available broadly aggregated input-output tables for 1995-7. It is overly restrictive because only ten sectors are present and the main important sectors of mining and manufacture are merged. 14

To come around data constraints, we choose the following strategy. We take the Russian inputoutput table for 1997 based on GKS [2000b, Table 4.3] and construct a more detailed table using RAS approach. ${ }^{15}$ The entries of the table are converted its entries into US dollars using sectoral price ratios introduced in the next section. The resulting cost-revenue structure shows what would happen with the Russian economy if it momentarily switches to the US prices. Assuming that the US prices are efficient, this experiment provides a numerical evaluation of the claim that Russian domestic prices hide the value-destroying nature of manufacturing sectors.

Our methodology of finding the transfer of value across sectors using shadow prices is similar to the approach pioneered in Corden [1966]. Corden asks the question of what is the value of protection that industry $j$ receives because of import tariffs on both good $j$ and material inputs used in its production. He determines the unit value transferred as

$$
\Delta \text { Value }_{j}=\text { Price }_{j} \times\left(\text { Tariff }_{j}-\sum_{i} \text { Tariff }_{i} \times \text { Coefficient }_{i j}\right)
$$

where Coefficient $i j$ is the share of input $i$ in the cost structure of $j$. In our case the unit value transferred can be found as

$$
\Delta \text { Value }_{j}=\left(\text { Price }_{j}^{U S}-\text { Price }_{j}^{\text {Rus }}\right)-\sum_{i}\left(\text { Price }_{i}^{U S}-\text { Price }_{i}^{\text {Rus }}\right) \times \text { Coefficient }_{i j}
$$

where Price $_{j}^{U S}$ is the US price of good $j$ in rubles. The latter term is introduced for illustrative purposes and is replaced with the individual price ratio introduced in the next section in actual calculations. 16

\section{The Assessment of Virtual Economy: Shadow Price's Approach}

In this section we test the proposition that if Russian economy uses shadow prices, we observe some sectors become value destroying. Formally, the test consists of two steps. First, shadow

\footnotetext{
more suited in other respects. In addition, the linguistic barrier makes German-Russian comparison a more challenging exercise for the author.

${ }^{14}$ The Department of Agricultural Economics at the Purdue University has constructed a worldwide input-output table containing 57 sectors (GTAP table). It contains estimates of elasticities and is used for trade modeling exercises. The table has the sub-table for the Commonwealth of Independent States that could serve as an approximation of Russian economy. We do not consider this table in our research because we believe it is less consistent with other Russian sources than the table reported by the GKS.

${ }^{15}$ See Appendix B for technicalities.

${ }^{16}$ The author is thankful to J. Clark Leith of the University of Western Ontario for pointing on the similarity of approaches.
} 
prices are found by using price ratios for economic sectors constructed below and, second, the ratios are used to recalculate sectoral revenues and costs.

We collect a sample of individual prices for the same goods and the same time period in both Russia and the USA assuming, initially, that goods do not differ in quality. Table B2 contains the list of 232 goods that we use in our investigation (see Appendix B). The individual price ratio of $\operatorname{good} j$ is found as

$$
\text { IndividualPriceRatio }_{j}=\frac{\text { Price }_{j}^{\text {Rus }}}{\text { Price }_{j}^{U S} \times \text { Factor }_{j}}
$$

where Factor $_{j}$ is the conyersion factor that is the ratio of the unit of measurement in Russia to the American unit of good $j .17$

Because we are interested in the sectoral price ratios, we have to choose a method of aggregation. It is standard in the literature to take the value of product as its weight. We have two estimates of values that can be taken individually or as a group: the values of Russian products measured at Russian and American prices. However, we have explicitly introduced the assumption that observed Russian prices are not market determined, which makes the proposition to use them as the weights to be inconsistent with the rest of the paper. Therefore, we calculate the weight of good $j$ using the US prices applied to Russian physical output

$$
\text { Weight }_{j}=\frac{\text { Price }_{j}^{U S} \times \text { Factor }_{j} \times \text { Output }_{j}^{\text {Rus }}}{\sum_{j \in I} \text { Price }_{j}^{U S} \times \text { Factor }_{j} \times \text { Output }_{j}^{\text {Rus }}}
$$

where $I$ is the set of goods belonging to the same sector.

Weighted individual rates are aggregated into sectoral price ratios following the All-Russian Product Classification OK-005-93 and All-Union Industrial Classification of National Economy $O K O N K h-1-75-018.18$ The formula for finding the price ratio for sector $I$ is

$$
\text { PriceRatio }_{I}=\sum_{j \in I} \text { IndividualPriceRatio }_{j} \times \text { Weight }_{j}
$$

\footnotetext{
${ }^{17}$ For example, one Russian ton contains 7.46 US barrels of crude oil in our calculations. The references to the unit conversion sources are at the bottom of Table B2.

${ }^{18}$ Classifications are issued by Russian State Committee for Standards on December 30, 1993 (a version is available at http://www.energomash.ru/OKP) and by All-Soviet State Committee for Standards on January 1, 1975 (available at http://www.standard.ru/classif/okonh/okonh.phtml).
} 


\section{William Davidson Institute Working Paper 428}

Table 1: The value of intermediate costs, output, and value-added in absolute values

\begin{tabular}{|c|c|c|c|c|c|c|}
\hline & & \multicolumn{2}{|c|}{$\begin{array}{l}\text { Input-output table } 1997 \\
\text { (in billion of rubles) }\end{array}$} & \multicolumn{3}{|c|}{$\begin{array}{c}\text { I/O '97 converted at price ratios (in million } \\
\text { of US dollars) }\end{array}$} \\
\hline & & Costs & Output & Costs & Output & $\begin{array}{l}\text { Value-added at } \\
\text { producer's price }\end{array}$ \\
\hline 1 & Electricity & - & 205,938 & 66,991 & 63,630 & $-3,361$ \\
\hline 2 & Oil extraction & 22,304 & 94,649 & 7,559 & 34,234 & 26,675 \\
\hline 3 & Oil processing & 84,907 & 142,427 & 31,154 & 31,732 & 577 \\
\hline 4 & Gas extraction & 20,447 & 60,483 & 9,461 & 126,588 & 117,127 \\
\hline 5 & Coal and other fuels mining & 19,120 & 41,751 & 7,485 & 20,820 & 13,335 \\
\hline 6 & Iron and steel & 90,701 & 121,366 & 33,938 & 29,576 & $-4,362$ \\
\hline 7 & Non-ferrous metallurgy & 45,673 & 91,429 & 15,231 & 23,196 & 7,965 \\
\hline (") & Chemical and petrochemical & 85,453 & 117,349 & 30,331 & 21,859 & $-8,472$ \\
\hline 9 & $\begin{array}{l}\text { Machine building and metal } \\
\text { processing }\end{array}$ & 163,308 & 291,945 & 61,701 & 132,096 & 70,395 \\
\hline 10 & Wood and paper & 39,869 & 61,810 & 13,187 & 21,502 & 8,315 \\
\hline 11 & Construction materials & 41,136 & 71,622 & 16,425 & 27,723 & 11,298 \\
\hline 12 & Textile, apparel, and footwear & 18,658 & 31,604 & 6,483 & 10,907 & 4,424 \\
\hline 13 & Food processing & 178,467 & 252,755 & 60,858 & 101,160 & 40,302 \\
\hline 14 & Other manufacturing & 22,194 & 41,320 & 9,279 & 52,049 & 42,770 \\
\hline 15 & Construction & 162,906 & 348,730 & 61,708 & 146,289 & 84,580 \\
\hline 16 & Agriculture and forestry & 170,718 & 322,565 & 61,618 & 73,010 & 11,392 \\
\hline 17 & Transportation & 120,877 & 363,137 & 44,444 & 152,332 & 107,888 \\
\hline 18 & Communications & 17,214 & 62,685 & 6,526 & 26,296 & 19,770 \\
\hline 19 & $\begin{array}{l}\text { Trade, intermediation, and food } \\
\text { services }\end{array}$ & 171,241 & 671,025 & 66,868 & 281,488 & 214,620 \\
\hline 20 & $\begin{array}{l}\text { Other activities related to goods } \\
\text { and services }\end{array}$ & 9,373 & 29,203 & 5,196 & 12,250 & 7,054 \\
\hline 21 & $\begin{array}{l}\text { Residential, communal, and } \\
\text { household services }\end{array}$ & 101,462 & 241,575 & 41,288 & 101,338 & 60,051 \\
\hline 22 & Health, education, and culture & 134,302 & 333,869 & 52,172 & 140,055 & 87,883 \\
\hline 23 & Science, geology, and meteorology & 34,229 & 65,511 & 13,518 & 27,481 & 13,963 \\
\hline 24 & Finance, credit, and insurance & 21,610 & 39,996 & 9,085 & 16,778 & 7,693 \\
\hline 25 & $\begin{array}{l}\text { State and business management } \\
\text { and } N G O\end{array}$ & 156,029 & 327,542 & 67,184 & 137,400 & 70,216 \\
\hline & Memo: Total & $2,026,706$ & $4,432,287$ & 799,690 & $1,811,788$ & $1,012,098$ \\
\hline
\end{tabular}

Sources: Data reported are from the input-output table for 1997 (see GKS [2000a], adjusted as explained in Appendix B); other columns are author's calculation. Sectors in italics are converted at the ratio of Russian GDP in rubles to its estimate at the PPP exchange rates.

Price ratios are constructed for 15 sectors only. The prices for other sectors are converted at the price ratio of Russian GDP expressed in rubles to the estimate of GDP calculated by the World Bank at the PPP exchange rate. 19

\footnotetext{
${ }^{19}$ Russian GDP stands at 2,523,542.3 billions of rubles by the GKS estimate (see GKS [2000b, Table 2.13]) and at 1,058.6 billions of US dollars by the World Bank estimate (see the 2001 World Development Indicators CD-ROM Win*STARS, Version 4.2, Series “GDP, PPP (current international \$)”). This amounts to 2383.85 Ruble/US \$.

In principle, it is possible to compare the value of services provided by the sectors of transportation, communications, and trade (see Ark and Timmer [2001]). However, such an exercise is not easy to defend methodologically. The use of prices originating in an analogue country rests on the implicit assumption that goods in both countries are substitutes. Services are not tradable by definition. Even if we have enough data to compare prices per ton-km of transportation, Russian consumers will not be able to receive American services at that price. The direct comparison of prices in sectors related to the provision of public services is impossible because the unit of measurement is absent.
} 
Table 1 presents the comparison of ruble and recalculated dollar values of sectoral revenue and total material costs in absolute values. The sum of recalculated value-added ( $\$ 1,012$ billion) comes close to the value-added estimated by the World Bank ( $\$ 1,059$ billion), which suggests that our procedure of finding sectoral price ratios is compatible with similar calculations.

The estimates of value-added at shadow prices show that there is significant transfer of value across the sectors. This finding indicates that Gaddy and Ickes might have found a distortion to be corrected. However, before we proceed with policy suggestions, let us consider what this finding implies. The sectors that are found generating negative value are electricity, iron and steel, and chemical and petrochemical manufacturing. These sectors are usually viewed as industries producing low-processing goods. It means that, along with mining, producers of highprocessed goods benefit if Russian prices converge to the world level, which is opposite to what Gaddy and Ickes expect. Another implication of the hypothesis appears to be dubious as well. According to Gaddy and Ickes if the "value-destroying" sectors go bankrupt, the economy will improve in the long run. They mean, apparently, that the output of the sectors can be replaced with import. In fact, the import of electricity accounts for less than one percent of total consumption and the share is unlikely to grow. The sector of iron and steel is a major exporting and not importing sector. The only sector whose products are imported significantly is chemical manufacturing but it is a large exporter as well. In total, it seems implausible that importing helps if bankruptcy is what envisioned for the sectors. Finally, our estimate of "new" GDP is lower than that calculated by the World Bank. Thus, the conjecture that GDP will grow at new prices does not hold the ground.

To take a closer look on the changes that have occurred after the price conversion, we have constructed Table 2. It shows the weighted ratios of revenue, costs, and value-added found as

$$
\text { Ratio }_{i}=\frac{\text { Value }_{i}^{\text {Rus }} \times \text { WBPriceRatio }}{\text { Value }_{i}^{U S}}
$$

where Value stands for either revenue or costs for sector $i$ and superscripts Rus and US mean its ruble and recalculated dollar value. WBPriceRatio is the ratio of GDP in rubles to the GDP estimate calculated by the World Bank at the PPP exchange rate.

Table 2 divides sectors into two groups according to whether their ratio of value-added is below or above half of the ratio for total economy. The first part comprises metallurgy, agriculture, and sectors that are heavily dependent on fuels: electricity, oil processing, and chemicals. Three of these sectors generate negative value-added and are "virtual" in the Gaddy and Ickes's sense. The rest come close. A casual look at their cost structure indicates that costs at shadow prices grow mostly due to the increase in prices of fuels (oil, gas, and coal) for all sectors apart from agriculture.

Let us take a closer look at three sectors, which generate negative value-added at the shadow prices. The change in the share of input cost is reported in Table 3. It is found as

$$
\text { ShareChange }_{i}=\frac{\text { Cost }_{i}^{\text {Con }}}{\text { Revenue }_{i}^{\text {Con }}}-\frac{\text { Cost }_{i}^{\text {Nom }}}{\text { Revenue }_{i}^{\text {Nom }}}
$$

\footnotetext{
${ }^{20}$ The latter is apparently supported with price floors.
} 
where superscripts Con denotes the revenue or total cost of input $i$ converted at the price ratio and Nom stands for the value determined at nominal (observable) prices.

Table 2: Relative values for sectors, for which sectoral price ratios are calculated; sorted by the magnitude of the ratio of the value-added; found using equation [6]

\begin{tabular}{|c|c|c|c|c|}
\hline & & Ratio of intermediate costs & Ratio of revenues & Ratio of value-added \\
\hline 1 & Chemical and petrochemical & 0.85 & 0.44 & -0.63 \\
\hline 2 & Iron and steel & 0.89 & 0.58 & -0.34 \\
\hline 3 & Electricity & 1.69 & 0.74 & -0.07 \\
\hline 4 & Oil processing & 0.87 & 0.53 & 0.02 \\
\hline 5 & Agriculture and forestry & 0.86 & 0.54 & 0.18 \\
\hline 6 & Non-ferrous metallurgy & 0.79 & 0.60 & 0.41 \\
\hline 7 & Textile, apparel, and footwear & 0.83 & 0.82 & 0.81 \\
\hline - & Oil extraction & (n) & 0.86 & 0.88 \\
\hline 9 & Construction materials & 0.95 & 0.92 & 0.88 \\
\hline 10 & Wood and paper & 0.79 & 0.83 & 0.90 \\
\hline (3) & Food processing & 0.81 & 0.95 & 1.29 \\
\hline 12 & $\begin{array}{l}\text { Machine building and metal } \\
\text { processing }\end{array}$ & 0.90 & 1.08 & 1.30 \\
\hline 13 & Coal and other fuels mining & 0.93 & 1.19 & 1.40 \\
\hline 14 & Other manufacturing & 1.00 & 3.00 & 5.33 \\
\hline 15 & Gas extraction & 1.10 & 4.99 & 6.97 \\
\hline & Total economy & 0.94 & 0.97 & 1.00 \\
\hline
\end{tabular}

Sources: Table 1 of this paper.

We see that the change in the cost of fuels coupled with changes in transport and trade margins are responsible for dropping value-added of the sectors to the negative territory. This structure of changes in the value of material cost is consistent with the observation made by Gaddy and Ickes: "three fat men" of Russian economy support other sectors with relatively low prices on their products. The reference of Gazprom helping to the sector of iron and steel that we have mentioned before appears to be reasonable as well.

While the importance of fuel costs is to be expected given our previous discussion, significance of transport and trade margins is more troubling. Recall that we do not calculate shadow prices for the sectors of transportation and trade but base their supposed "market" values on the World Bank estimate of Russian GDP at the PPP exchange rate. If the shadow prices for sectors with non-tradable services are evaluated at the official exchange rate instead, chemical manufacturing remains the only sector with the negative value-added on conversion. Therefore, the significance of transport and trade on conversion depends critically on the assumption about the relative productivity of these sectors that we make.

Up to now we have proceeded on the assumption that the US prices are representative of the market value of Russian goods. In fact, it might not be the case. Usually, Russian goods are considered to be of inferior quality compared with its Western counterparts. We want to explore if adjusting for quality change the results obtained so far.

\footnotetext{
${ }^{21}$ They are natural gas monopoly Gazprom, the Ministry of Railroads, and the United Electric System that controls the national power grid.
} 
Table 3: The changes in material input cost shares for the sectors with the negative value-added recalculated

\begin{tabular}{|c|c|c|c|c|c|}
\hline & & Electricity & $\begin{array}{l}\text { Iron and } \\
\text { steel }\end{array}$ & $\begin{array}{l}\text { Chemical and } \\
\text { petrochemical }\end{array}$ & $\begin{array}{l}\text { Simple average } \\
\text { cost change }\end{array}$ \\
\hline (3) & Gas extraction & 0.474 & 0.099 & $\begin{array}{l}0.216 \\
0 .\end{array}$ & 0.263 \\
\hline (2) & 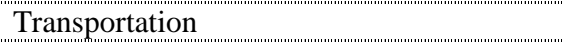 & 0.050 & 0.080 & 0.096 & 0.075 \\
\hline 3 & Electricity & 0.000 & 0.030 & 0.136 & 0.055 \\
\hline 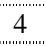 & Trade, intermediation, and food services & 0.024 & 0.046 & 0.058 & 0.043 \\
\hline ' & Coal and other fuels mining & 0.031 & 0.088 & 0.008 & 0.042 \\
\hline 6 & Machine building and metal processing & 0.011 & 0.028 & 0.037 & 0.026 \\
\hline 7 & Other manufacturing & 0.008 & 0.012 & 0.029 & 0.016 \\
\hline 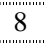 & Science, geology, and meteorology & 0.000 & 0.006 & 0.017 & 0.008 \\
\hline 9 & $\begin{array}{l}\text { Other activities related to goods and } \\
\text { services }\end{array}$ & 0.001 & 0.005 & 0.006 & 0.004 \\
\hline 10 & Wood and paper & 0.000 & 0.001 & 0.010 & 0.004 \\
\hline 11 & Construction & 0.001 & 0.004 & 0.006 & 0.004 \\
\hline 12 & Communications & 0.000 & 0.002 & 0.006 & 0.003 \\
\hline 13 & Construction materials & 0.000 & 0.001 & 0.005 & 0.002 \\
\hline 14 & Iron and steel & -0.001 & -0.001 & 0.008 & 0.002 \\
\hline 15 & Oil extraction & 0.000 & 0.000 & 0.006 & 0.002 \\
\hline 16 & Food processing & 0.000 & 0.000 & 0.004 & 0.002 \\
\hline '17m & Finance, credit, and insurance & 0.001 & 0.001 & 0.002 & 0.001 \\
\hline 18 & $\begin{array}{l}\text { Residential, communal, and household } \\
\text { services }\end{array}$ & 0.000 & 0.001 & 0.002 & 0.001 \\
\hline 19 & State and business management and NGO & 0.000 & 0.001 & 0.001 & 0.001 \\
\hline 20 & Non-ferrous metallurgy & 0.000 & 0.000 & 0.001 & 0.000 \\
\hline 21 & Health, education, and culture & 0.000 & 0.000 & 0.000 & 0.000 \\
\hline 22 & Textile, apparel, and footwear & 0.000 & 0.000 & 0.000 & 0.000 \\
\hline 23 & Agriculture and forestry & 0.000 & 0.000 & 0.000 & 0.000 \\
\hline 24 & Oil processing & -0.007 & -0.001 & 0.005 & -0.001 \\
\hline \multirow[t]{2}{*}{25} & Chemical and petrochemical & -0.002 & -0.002 & -0.001 & -0.002 \\
\hline & $\begin{array}{l}\text { The change in material costs to revenue } \\
\text { ratios }\end{array}$ & 0.593 & 0.400 & 0.659 & 0.551 \\
\hline
\end{tabular}

Sources: Author's calculations

It is not clear from economic literature how to measure quality. One suggestion is to compare domestic prices for Russian and imported goods with similar functional properties. The difference in prices, if any, provides a quantitative estimate of quality on the basis of revealed preferences. Unfortunately, this approach is infeasible due to data constraints.

We propose a different method. Assuming that capital and labor is less productive in Russia, the degree of processing for sectors can serve as a weighting coefficient that introduces quality in the evaluation of shadow prices for domestic goods. The next step is to determine the methodology for finding the degree of processing.

First, the sectors are divided in primary and processing. Essentially, we list primary goods and find the share of its value in total revenue using data on the composition of sectoral output (see Appendix D for details). The primary good is defined to be a good naturally available such as minerals, raw fuels, and unprocessed lumber plus raw agricultural products and electricity.

Next, we calculate the index of processing, which is the processing value accrued to the unit value of primary inputs. While the actual formula that finds the index includes values of intermediate input (see formula [D1] of Appendix D), it becomes the ratio of the costs of primary goods to the total revenue if intermediate inputs are ignored 
IndexProcessing $=\frac{\sum \text { PrimaryCost }_{k}}{\text { Revenue }}$

Appendix D contains calculations and the estimates of the indices of processing.

The indices found cannot be used in determining shadow prices like we have done before. They are calculated on the assumption that processing is 'virtual', in the sense that it does not add any value to the final product. ${ }^{22}$ Thus, the impact that the introduction of estimated quality would have on the value-added generated by sectors is to be assessed differently.

We consider the proposition that domestic prices come closer to shadow prices if adjusted for quality is a natural supplement to the hypothesis of virtual economy. If quality is the parameter that biases our results, its inclusion should reduce the gap. Then, the variance for the sample of ratios adjusted is to be smaller than for the same sample involving unadjusted ratios. The results are reported in Table 4 . The variance is calculated around the mean normalized to unity.

Table 4: Price ratios unadjusted and adjusted by the degree of processing

\begin{tabular}{|c|c|c|c|}
\hline & Sector & Unadjusted Price Ratio & Adjusted Price Ratio \\
\hline 1 & Electricity & 3,237 & 3,237 \\
\hline 2 & Oil extraction & 2,765 & 2,765 \\
\hline 3 & Oil processing & 4,488 & 2,622 \\
\hline 4 & Gas extraction & 478 & 478 \\
\hline 5 & Coal and other fuels mining & 2,005 & 2,005 \\
\hline 6 & Iron and steel & 4,103 & 2,697 \\
\hline 7 & Non-ferrous metallurgy & 3,942 & 2,369 \\
\hline 8 & Chemical and petrochemical industry & 5,368 & 3,255 \\
\hline 9 & Machine building and metal processing & 2,210 & - n \\
\hline 10 & Wood and paper & 2,875 & 1, 1,586 \\
\hline 11 & Construction materials & 2,583 & 1,207 \\
\hline 12 & Textile, apparel, and footwear & 2,898 & 1,432 \\
\hline 13 & Food processing & 2,499 & 1,483 \\
\hline 14 & Other industries & 794 & 326 \\
\hline \multirow[t]{2}{*}{15} & Agriculture and forestry & 4,418 & 4,418 \\
\hline & $\begin{array}{l}\text { Variance (around the mean normalized to } \\
\text { unity) }\end{array}$ & 0.204 & 0.315 \\
\hline
\end{tabular}

Sources: Column 1 is from Table 1, column 2 is the product of column 1 of this table and column 2 of Table D1.

The result reported in Table 4 does not show that the adjustment for quality reduces the variance of price ratios. Thus, we cannot state that quality, approximated by the degree of processing in this case, is an important factor that biases our results.

\section{Explaining Price Differentials}

The results obtained lead to the question of why price ratios differ so remarkably across the sectors. There are several potentially valid hypotheses to be explored.

Suppose the processing is less productive in Russia, in the sense that the same level of processing results in the production of goods of lower quality. Then, the ratio of domestic to American prices should fall as the degree of processing increases.

\footnotetext{
${ }^{22}$ The latter carries forward the value of primary goods spent in the production.

${ }^{23}$ Technically, we divide the variance by the average price ratio in second power.
} 
The same result is obtained if the cost of factors of production relative to the cost of inputs is lower in Russia. Then, the more processing is involved, the less is the relative price of domestically produced goods given that markets are competitive.

We use the index of processing introduced in the previous chapter and regress it on the price ratios. Figure 1 presents a scatter diagram of the index of processing and price ratio. It shows that the parameters are positively correlated. Statistical analysis supports this claim. The OLS regression finds that

$$
\text { PriceRatioNormalized }=-0.410+1.848 \times \text { IndexProcessing }
$$

with t-statistics for $\beta$ being 3.02, which is significant at the 98 percent level. The correlation coefficient is 0.753 .

Figure 1: Scatter diagram of the index of processing (Table D1) and price ratio (rubles per dollar scaled, Table B3, general consumption) for 10 processing sectors.

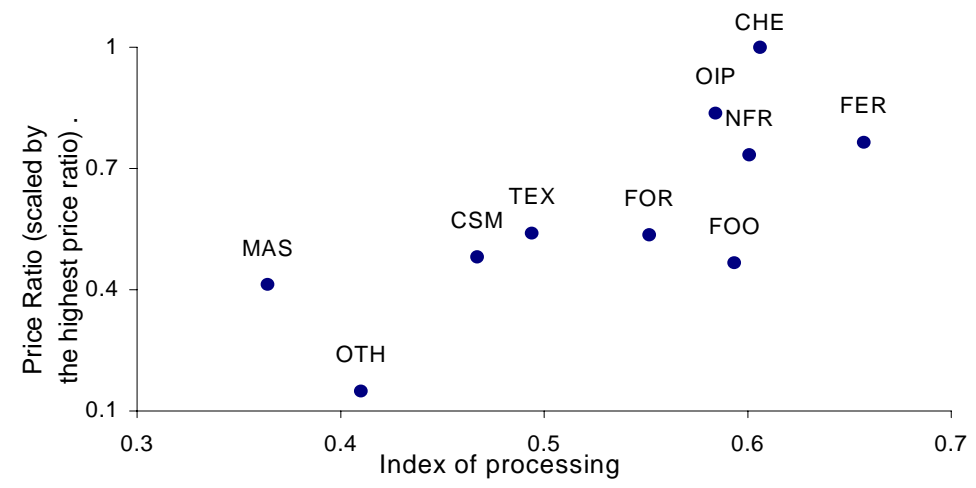

Let us consider what the detected correlation implies. The index of processing represents, in its simple form, the ratio of unit cost of primary inputs to the value of processed output. The other variable represents the ratio of Russian to American values of the processed goods. As the index of processing falls, which corresponds to a higher level of processing, Russian goods become relatively cheaper compared to their US counterparts.

Since we do not discriminate between the difference in quality (as we have assumed before) and the relative cost of factors of production, it is unclear what of two reasons is the most important. Yet, in both cases domestic prices convey information on the market evaluation of goods, which contradicts the proposition that they are 'virtual'.24

Another explanation of the price differentials is that Russian prices, unlike its American counterparts, include additional charges such as interest on overdue trade credit or transaction costs associated with barter.

The late payment is expected to rise as the flow of receivables that firms accumulate increases. 25 The scatter diagram of the share of the change in receivables to total trade and price ratios is presented on Figure 2. It shows that the parameters are weakly negatively correlated. The OLS regression finds that

\footnotetext{
${ }^{24}$ The correlation between the index of processing and price ratio is not very robust. The author has attempted to add agriculture and electricity to processing sectors because they do not fit the definition of primary industries provided above and t-statistics has dropped below the $95 \%$ significance level.

${ }^{25}$ We choose the flow over stock of receivables as being closer related to the time frame that we cover.
} 
with t-statistics for $\beta$ being -0.94 , which is significant at the 63 percent level. The correlation coefficient is -0.251 .

Figure 2: Scatter diagram of the changes in receivables (in percent to revenue, Table A5) and price ratios (rubles per dollar scaled, Table B3, general consumption) for 15 sectors.

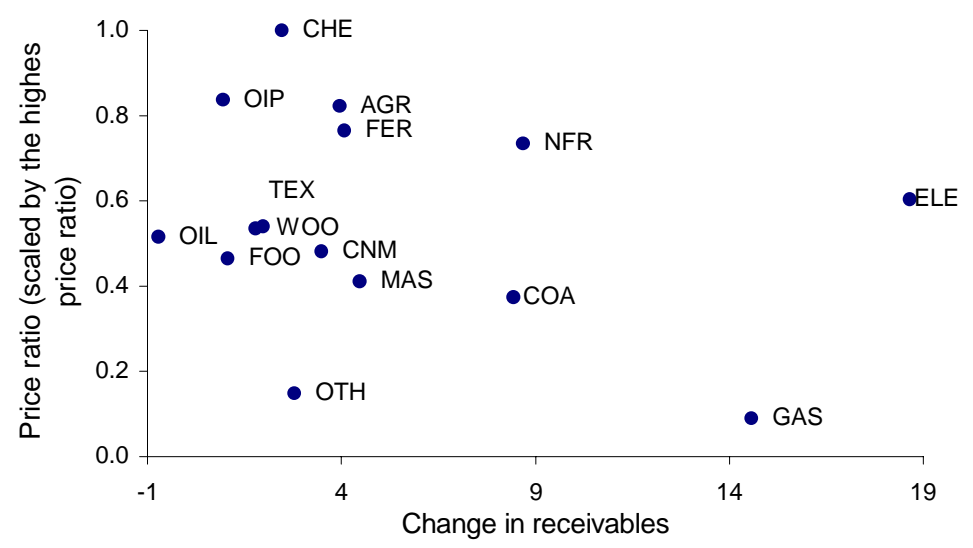

Figure 3 depicts the relationship between the shares of barter in trade and price ratios. The parameters appear to be weakly positively correlated. The OLS regression finds that

$$
\text { PriceRatioNormalized }=0.222+0.006 \times \text { BarterShare }
$$

with t-statistics for $\beta$ being 1.32, which is significant at the 79 percent level. The correlation coefficient is 0.343 .

Both single regressions do not find that the difference in trade practices is an important explanation of price differentials. This result suggests that the emphasis of peculiar trade arrangements as the main price distortions is misplaced.

Next, we consider whether the difference in prices detected can be attributed to import barriers. 26 To determine the relative sizes of tariff regulations, we take import tariff rates effective in 1997 and find sectoral rates using the same aggregation procedure as used in the construction of price ratios. We consider that domestic price regulation amounts to trade barrier on export and add the difference between domestic and export price to tariff rates for affected sectors. 27 The general formula that finds the rate of price protection for product $j$ is

\footnotetext{
${ }^{26}$ We exclude the issue of export barriers because it requires constructing tariff structures for main Russian trade partners, which is complicated and, in general, irrelevant to the allegation of inflated values of output that we explore.

${ }^{27}$ The last consideration affects the sector of natural gas extraction only. While the domestic price for electricity is similarly controlled, it is higher than uncontrolled export price. This fact suggests that it is price floor that is set domestically and not price ceiling. Since export and import prices are practically identical $(\$ 24.26$ and $\$ 24.31$ per $1,000 \mathrm{~kW}-\mathrm{H})$, we consider that electricity sector is tariff-protected.
} 


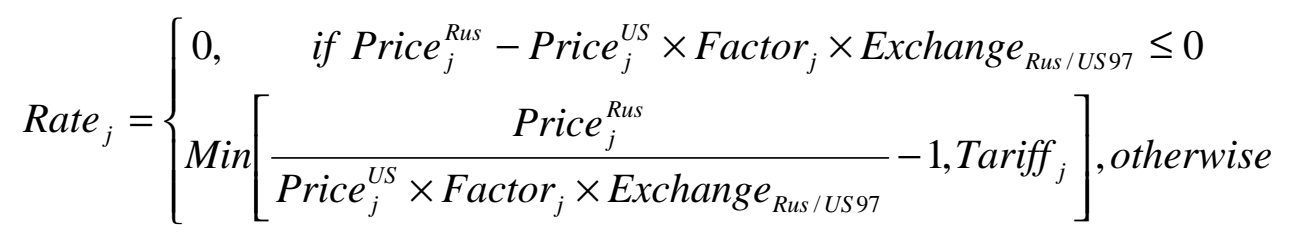

where Exchange Rus $_{\text {US97 }}$ is the market exchange rate for 1997. Appendix C explains the procedure for calculating rates and contains the table of its estimates.

Figure 3: Scatter diagram of the barter share (in percent to total revenue, Table A6) and price ratios (rubles per dollar scaled, Table B3, general consumption) for 15 sectors.

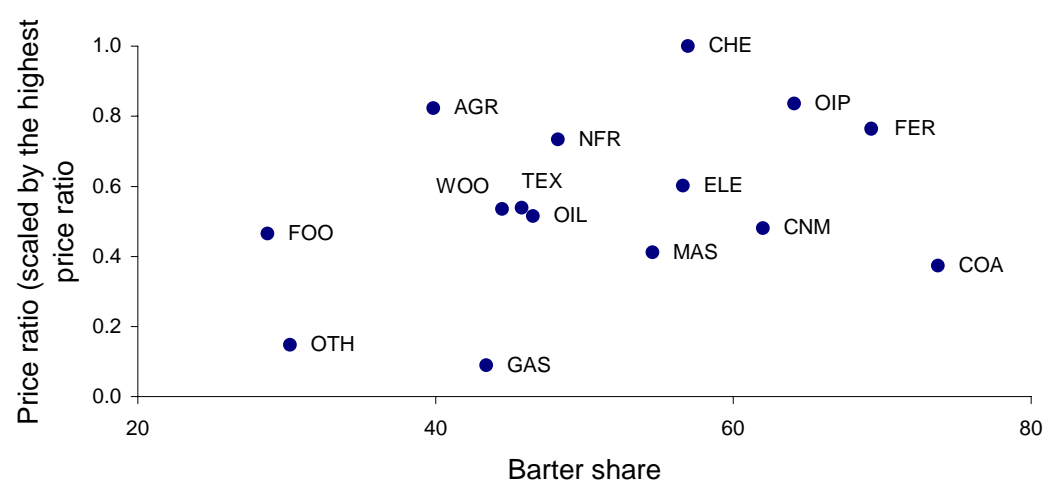

We expect that if import barriers explain price differences between domestic and world market prices, they should be positively correlated with price ratios. The scatter diagram of tariff protection rates and price ratios is shown on Figure 4. It indicates that a slight positive correlation is present. The regression shows that

PriceRatioNormalized $=0.572+0.012 \times$ ProtectionRates

with t-statistics for $\beta$ being 2.38 , which is significant at the 96 percent level. The correlation coefficient is 0.552 .

This result is to be expected. According to the theory, in the perfect world the price arbitrage is eventually dissipated as traders take the opportunity to earn extra profit. The only difference in prices remaining is the value of trade barriers. Both the sign and the significance of our result are congruent with the theory. $\frac{28}{}$

Single variable regression analysis shows that modes of trade are not significantly correlated with the price ratios. Let us check that multivariate regression yields a similar result. We regress all four parameters of interest on the price ratio getting

$$
\begin{aligned}
\text { PriceRatioNormalized } & =-0.784+0.010 \times \text { BarterShare }+0.016 \times \text { ChangeReceivables }+ \\
& +1.347 \times \text { IndexProcessing }+0.052 \times \text { ProtectionRates }
\end{aligned}
$$

with t-statistics for coefficients being $2.81,0.68,2.57$, and 1.37 respectively.

\footnotetext{
${ }^{28}$ However, the significance depends critically on the sector of gas extraction, which is an outlier. Without this sector, the level of significance drops to 1.291 .
} 
Figure 4: Scatter diagram of the protection rates (in percent to total revenue, Table C1) and price ratios (rubles per dollar scaled, Table B3, general consumption) for 15 sectors

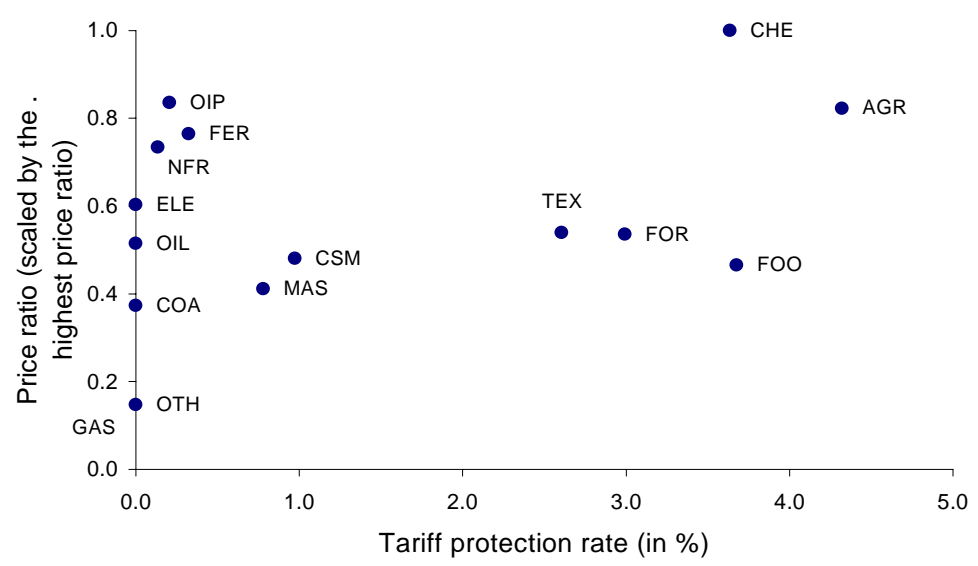

Since the change in receivables and protection rates do not appear to explain price differentials, we reduce the number of parameters and run a bivariate regression

$$
\text { PriceRatioNormalized }=-0.7+0.008 \times \text { BarterShare }+1.628 \times \text { IndexProcessing }
$$

T-statistics for coefficients improves to 2.53 and 3.42, which is significant on the 95 percent level. Adjusted R-square is 0.715 for the exercise.

We conclude that both the use of barter and the difference in processing explain much of the detected price variation. These factors make opposite impacts: while the use of barter rises Russian prices relative to the US level, more processing lowers them. The growth in trade arrears and protection tariffs appear to have insignificant impact on prices. The first finding implies that traders do not systematically account for possible delay in payments. The second suggests that a statistically significant relationship between import fees and price differentials that we have found in [13] is not robust, the fact that we have already mentioned in footnote [35].

Finally, we consider if individual Russian prices possess inertia remained from the Soviet time. This exercise addresses the conjecture that Russia has simulated market reforms preserving, in fact, a command economy with state-regulated prices.

Defining inertia is not a straightforward exercise. We have to determine an initial position, target, and the speed of approaching the target. Let Russian pre-transition prices of 1991 be the beginning and the US prices of 1997 - the target, while the position that Russian prices had in 1997 be measuring the speed of approaching the target if any progress is present.

Since prices are measured in different units (pre- and mid-transition rubles and dollars), it is necessary to bring them to the same denominator. We propose to use the price of some basic product as the numeraire. Since the prices of electricity and gas were controlled in Russian transition, the price of one metric ton of oil is chosen.

Russian prices for 1991 are recalculated from average prices for December 1991 and price indices available for a sequence of years 1992-7 for 140 goods out of 232 present in the sample. We use data from GKS [1998d, tables 2.18, 2.20, 4.6, 6.8]. The regression of Russian prices of 1991 and US prices of 1997 on Russian prices of 1997 yields the following result 


$$
\text { RusPrice } 97=-0.418+0.356 \times \text { RusPrice } 91+0.056 \times \text { USPrice } 97
$$

with t-statistics being 13.39 and 5.97 respectively. Both parameters are significant at the 99 percent level.

The correlation detected is hardly surprising because the sample includes relatively cheap and expensive products that preserve their ranking in time and across the border. The important thing is that both parameters explain a portion of the Russian prices of 1997 in our sample and not contradict one another. The single regressions find that the Russian prices of 1991 serve as a better explanation than the US prices of 1997. While together they are able to explain 0.877 of the variance, the first explains 0.845 and the second -0.716 . Therefore, price inertia appears to be significant. Still, the impact of the world prices cannot be rejected on the basis of found evidence.

\section{Conclusion}

In this paper we have extended the discussion on the nature of transitional Russian price structure to the field of empirical research. The previous discourse has generated a large number of propositions that have not been tested in a systematic manner.

We have taken the hypothesis of virtual economy as our starting point and checked the proposition that Russian domestic prices have been deliberately distorted to conceal the valuedestroying nature of economically non-viable but politically important sectors. We have recalculated the value-added for economic sectors using the method of shadow pricing and found that three out of fifteen sectors correspond to the definition of value destruction in the sense that at shadow prices the cost of material inputs exceeds the value of its output. Moreover, the analysis of their shadow cost structure indicates that the main cost increases are associated with the inputs supplied by state-controlled monopolies. This finding is consistent with the proposition that politics is involved in price setting in Russian transition.

The sectors that are found generating negative value are electricity, iron and steel, and chemical and petrochemical manufacturing. These sectors are usually viewed as industries producing lowprocessing goods. Other sectors, including producers of high-processed goods, benefit if Russian prices converge to the world level. This finding is opposite to what Gaddy and Ickes suggest: prices are distorted to support sectors at the high-processing end.

The implication of the hypothesis that if the "value-destroying" sectors go bankrupt the economy will improve in the long run appears to be dubious. First, it means, apparently, that the output of the outgoing sectors can be replaced with import. In fact, the import of electricity is miniscule and its share is unlikely to grow on technical grounds. Iron and steel is a major exporting and not importing sector. Therefore, we have to assume that its export is subsidized by the state to infer that the closure of the sector increases GDP in the long run. This is a bold statement and seems unlikely at the moment. The only sector whose products are imported in a large degree is chemical manufacturing and, if it goes out of business, the GDP might eventually grow. Yet, taken together, it seems implausible that importing helps if bankruptcy is what Gaddy and Ickes envision for these sectors. Second, our estimate of "new" total GDP is lower than that calculated by the World Bank. Thus, the conjecture that combined effect of the closure on GDP will be positive is overstretched. 
These results have been obtained using the assumption that the US prices are representative of the market value of Russian goods, which ignores the problem of quality variation. We have proposed to use the degree of processing as a proxy for quality and considered if accounting for it brings prices closer. The result has been negative implying that quality is not a significant factor that biases our findings.

We have attempted to explain the detected differences in prices by testing several hypotheses both individually and as a group. We have regressed the relative cost of factors to material inputs, barter and receivables shares in revenue, and effective trade tariffs on price ratios. The results indicate that accounting for differences in the values of factors of production explains a significant portion of price differentials. Since we do not discriminate between the difference in quality (as we have assumed before) and the relative cost of factors of production, it is unclear what of two reasons is the most important. Yet, in both cases domestic prices convey information on the market evaluation of goods, which contradicts the proposition that they are 'virtual'.

The use of barter appears to influence Russian prices but only in a multivariate regression. The change in accumulated trade receivables has an insignificant impact. This result suggests that the emphasis on peculiar trade arrangements as being the main driving force determining domestic prices is misplaced.

The positive impact that effective tariff rates have on prices is to be expected according to the theory and it is shown to be present. Yet, the result is not robust and depends on the price control for the sector of gas extraction to stay statistically significant. This finding indicates that domestic traders practically discount tariffs while setting prices.

Finally, we have considered if individual Russian prices possess inertia remained from the Soviet time. Brought to the same numeraire, domestic prices in transition show positive and significant correlation with both pre-transition prices and world level. This finding implies that Russian prices have been relatively inflexible in transition, which leads to two potential interpretations. The first is congruent with the previous statement of politics being involved. It is possible that interest groups remained from the Soviet time resist price changes. Another explanation is that Soviet price administrators did in fact a good job and major market corrections have been unnecessary in transition. ${ }^{29}$ The fact that domestic prices have moved closer to world level indicates unequivocally that the Russian economy becomes more open. The last statement seems to be uncontroversial.

Regarding the hypothesis of virtual economy, the evidence is either ambiguous or unfavorable to it. To serve as a building block towards the theory of economic transition, the hypothesis is to be better structured and generate clear predictions. It appears that, in its present form, the hypothesis belongs to the area of bold conjectures, which is not testable by definition.

The general impression from the exercises conducted is that the structure of Russian price system is not well understood. It would be interesting to learn more about what kind of market signals transitional prices convey (or suppress) and why. This line of research will advance our

\footnotetext{
${ }^{29}$ Taking into account that the Soviet Price Committee (Goskomzen) used the practice of average cost setting (similar to that popularized by Andrei Shleifer in his “A Theory of Yardstick Competition", Rand Journal of Economics, 16, 3: 319-27 Autumn 1985), the statement that market price corrections might be small in transition should not be discounted. The problem of efficient allocation of the factors of production is another matter: given the present disposition of factors, prices can be efficient.
} 
understanding of both the behavior of Russian economy in transition and how markets work after a major shock in general.

The issue of barter and arrears and why they have become so widespread in transition is important in itself. Do non-monetary modes of exchange represent a normal evolutionary development for an emerging market or they are anomalies outside of the market? Answering this question will enable us to better understand the nature of transition and contribute to the discussion that the proponents and opponents of the Washington Consensus continue to lead. 


\section{Appendix A: Non-monetary Exchanges in the Russian Transition}

Since non-monetary exchanges play a prominent role in the hypothesis, it is necessary to consider how important they were in 1997. Available data is sketchy and we attempt to systematize it here. We divide the presentation in two sections depending on the source of information.

\section{Section A1: Statistical and Survey Data}

The existing research on the role that barter and arrears play in transition is built around two sources of information: surveys of industrial enterprises and statistics provided by governmental offices.

Aukutsionek [1998] presents a sample of about 200 companies 30 whose managers have answered the question on the share of barter deals in its sales (see Table A1, sorted by magnitude). This work is apparently the first investigation of the phenomenon of barter in Russia and it has attracted considerable attention.

Table A1: Barter shares in sales for manufacture and agriculture, first half of 1997

\begin{tabular}{|c|c|c|}
\hline & Industry & $\begin{array}{l}\text { Barter share in } \\
\text { sales, \% }\end{array}$ \\
\hline (1) & Construction materials & 59 \\
\hline 2 & Ferrous and non-ferrous metallurgy & 56 \\
\hline 3 & Chemical and petrochemical & 52 \\
\hline 4 & Electricity & 46 \\
\hline 5 & Wood and paper & 46 \\
\hline 6 & Textile, apparel, and footwear & 42 \\
\hline 7 & Machine building and metal processing & 41 \\
\hline 8 & Fuel mining, extraction, and processing & 33 \\
\hline 9 & Agriculture & 31 \\
\hline 10 & Other manufacturing & 27 \\
\hline \multirow[t]{2}{*}{11} & Food processing & 25 \\
\hline & Memo: Simple average for the sectors & 42 \\
\hline
\end{tabular}

Source: Aukutsionek [1998], Table 2. Sample size is about 200.

The Institute of Economic Transition [IET, 2001] has conducted a different survey. It uses a sample of about 1,000 enterprises and asks about the importance of barter in both sales and purchases (see Table A2, sorted by magnitude in sales). These two surveys differ by both sectoral organization and time period covered.

The IET finds that the shares of barter in sales and purchases are highly correlated with the correlation coefficient being 0.964 . This result is reasonable because the accounting values of exchanged goods should be the same in sales and purchases.

A comparison of both surveys shows that barter was more likely to occur in the sectors of chemical manufacturing and ferrous metallurgy and less likely in food processing. While it is

\footnotetext{
${ }^{30}$ The English version of the publication explains that the rate of response varied around 200 whereas the number of approached companies was about 500. The Russian Economic Barometer has prepared the questionnaire.

${ }^{31}$ The subsequent work traditionally refers to this paper (see Woodruff [1999, Fig. 4, p.148], Desai and Idson [2000, Table 11.2, p.175], and Treisman [2000] among others).
} 
hard to propose a hypothesis explaining the ubiquity of barter in the first two sectors, the example of food procession suggests that the producers of final goods receive payments in cash relatively more often.

The results obtained in two surveys are somewhat incongruent. ${ }_{22}$ This finding indicates that either the share of barter varied in 1997 or sampling errors are present.

Table A2: Barter shares in sales and purchases for manufacture for 1997

\begin{tabular}{|c|c|c|c|}
\hline & Industry & $\begin{array}{l}\text { Barter share in } \\
\text { sales, } \%\end{array}$ & $\begin{array}{l}\text { Barter share in } \\
\text { purchases, } \%\end{array}$ \\
\hline 1 & Ferrous metallurgy & 64 & 73 \\
\hline 2 & Chemical and petrochemical & (3) & 71 \\
\hline 3 & Machine building and metal processing & 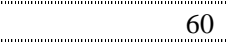 & 63 \\
\hline 4 & Textile, apparel, and footwear & 58 & 60 \\
\hline 5 & Construction materials & 54 & 64 \\
\hline 6 & Wood and paper & 51 & 55 \\
\hline 7 & Non-ferrous metallurgy & 38 & 30 \\
\hline 8 & Food processing & 21 & 22 \\
\hline & Memo: Simple average for the sectors & 51 & 55 \\
\hline
\end{tabular}

Source: IET [2001], Tables 1 and 2. Sample size is about 1,000.

Data on tax offsets - that are barter equivalents for government-business relationships - are unavailable in disaggregated form. The website of the Russian Ministry for Taxes and Fees reports that taxpayers contributed 152,004 billion rubles in cash to the Federal Budget and 184,361 billion rubles to other budgets. Given that the total tax collection by the Federal and other levels of government was 243,548 and 328,989 billion rubles respectively, 34 the share of tax offsets to tax collection were $37.6 \%$ for the federal and $44.0 \%$ for the territorial budgets. If we add the change in tax arrears for 1997 as being implicit subsidies (30,100 and 23,540 billion to the federal and territorial budgets, see GKS [1998b, Table 2.17]), the share of barter and arrears to assessed taxes rises to $44.4 \%$ and $47.7 \%$ respectively. These numbers are about the same as the share of inter-enterprise barter reported in Tables 1 and 2. This observation is inconsistent with the claim that unwanted goods have been ultimately dumped to the government.

It is reasonable to expect that a part of the bills be paid to the extra-budgetary funds in-kind. Gaddy and Ickes provide anecdotal evidence on social offsets (see Gaddy and Ickes [1998b, Appendix]. ${ }^{35}$ Yet, we have found no statistical data on the value of offsets that extra-budgetary funds granted to payers.

\footnotetext{
${ }^{32}$ The correlation coefficient for 7 sectors present in both tables is 0.692 , metallurgy combined with the same weight.

${ }^{33}$ See http://www.nalog.ru/stats/new/zhiv97-98-99.shtml

${ }^{34}$ See Table 9 in IET, "Russian Economy: Trends and Perspectives, Year 1997, Issue 18", available at http://www.iet.ru/ (in Russian).

${ }^{35}$ They cite a newspaper report that claims that a Samara chemical plant paid in pesticides for some undisclosed obligations and this product eventually became the property of the Pension Fund of the Republic of Mari El. It is unclear from the citation whether the payment was made directly to the Pension Fund or the Federal Government has collected taxes in-kind and transferred the goods to the Pension Fund. The Federal Government is obliged to contribute to the pension funds for federal employees.
} 
Data on the payment of wages in-kind is reported in the Russian Longitudinal Monitoring Survey (RLMS) in section "Adult Questionnaire". We process 4,234 entries, for which matching of the reported occupation with a particular economic sector is possible (job descriptions are taken from the International Labor Organization codes for primary occupations) and present them in Table A3.

Table A3: The share of in-kind payments for a sample of respondents, sorted by magnitude

\begin{tabular}{|c|c|c|c|}
\hline & Sector & Number of Observations & $\begin{array}{c}\text { The share of in-kind payment } \\
\text { in total labor income, } \%\end{array}$ \\
\hline 1 & Agriculture and forestry & 298 & 35.3 \\
\hline 2 & Chemical and petrochemical & 53 & 16.5 \\
\hline 3 & Iron and steel & 70 & 15.3 \\
\hline (3) & Food processing & 45 & 12.6 \\
\hline 5 & Coal and other fuels mining & 20 & 12.0 \\
\hline 6 & Construction & 230 & 11.9 \\
\hline 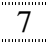 & Oil extraction & 3 & 11.4 \\
\hline - & Finance, credit, and insurance & 15 & 11.1 \\
\hline 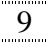 & Machine building and metal processing & 464 & 8.0 \\
\hline 10 & Transportation & 418 & 7.6 \\
\hline (3) & Other activities related to production and services & 96 & 6.9 \\
\hline 12 & Residential, communal, and household services & 462 & 6.1 \\
\hline 13 & Electricity & 87 & 5.8 \\
\hline 14 & Trade, intermediation, and food services & 493 & 4.3 \\
\hline (15 & Oil processing & 8 & 2.7 \\
\hline 16 & State and commercial management and NGO & 540 & 2.4 \\
\hline 17 & Textile, apparel, and footwear & 58 & 2.1 \\
\hline 18 & Health, education, and culture & 650 & 1.8 \\
\hline 19 & Science, geology, and meteorology & 99 & 1.6 \\
\hline 20 & Communications & 69 & 1.2 \\
\hline 21 & Construction materials & 13 & 0.6 \\
\hline 22 & Wood and paper & 23 & 0.4 \\
\hline 23 & Other manufacturing & 20 & 0.0 \\
\hline & Memo: Total number and weighted average & 4,234 & 6.4 \\
\hline
\end{tabular}

Source: Author's calculations based on RLMS, Round 7, Adult Questionnaire.

Table A3 shows that the payment of wages in kind occurs less frequently than inter-enterprise barter. This observation is consistent with the previous suggestion that barter is not common for final goods.

The numbers in tables A1-3 indicate the low bound of non-monetary trade because they apparently exclude specific modes of exchange. Regarding inter-enterprise barter, it is unclear whether the respondents consider such non-monetary means of exchange as bills of exchange issued by large industrial companies. In general, they are expected to be paid in cash on maturity but if a company refuses to honor a bill, the bill holder is presented with a difficult choice. Since initiating bankruptcy is a costly exercise, sometimes it is easier to find a buyer getting paid with a discount. As a result, there is a market for these bills, which begin circulating as quasi-money. Then managers might confuse non-payable (in cash) bills of exchange with money even if the

\footnotetext{
${ }^{36}$ Round VII. Data were collected for the period from September to November 1996. The web-site of the project is at http://www.cpc.unc.edu/projects/rlms/

${ }^{37}$ See http://www.cpc.unc.edu/projects/rlms/data/occupationalcoding.html for details.
} 
former is traded at heavy discount. As to the wages paid in-kind, the RLMS respondents were

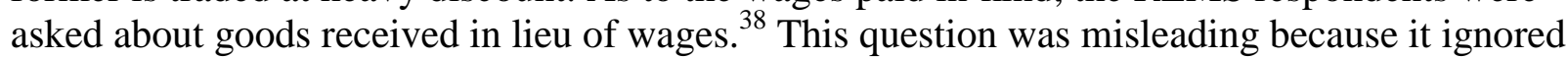
such modes of in-kind payment as credit extended at stores belonging to the firm to cover wage arrears and agreements to pay in-kind for utilities that many firms established with local providers.

Data on arrears come mostly from the State Committee on Stafistics (GKS, in Russian abbreviation) that reports overdue credit and debit accounts. In addition, Clarke [1997] supplies numbers on wage arrears that fill gaps for fuel industries. The Center for Economic conjuncture at the Russian Government provides a relatively detailed account on tax arrears for JanuarySeptember 1997 (see CEC [1998]). Table A4 presents the stock of arrears at the beginning of 1997 and Table A5 details the flows sorted by the share of arrears in sales.

Table A4: Arrears at the beginning of 1997, in percent of sector's revenue for that year, sorted by the share of receivables

\begin{tabular}{|c|c|c|c|c|c|c|c|}
\hline & & Receivables & $\begin{array}{c}\text { Total } \\
\text { payables }\end{array}$ & $\begin{array}{l}\text { Trade } \\
\text { arrears }\end{array}$ & $\begin{array}{c}\text { Tax } \\
\text { arrears }\end{array}$ & $\begin{array}{l}\text { Social Funds } \\
\text { arrears }\end{array}$ & $\begin{array}{l}\text { Wage } \\
\text { arrears }\end{array}$ \\
\hline 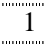 & Gas extraction & (2) & 62.6 & 34.2 & ( & 5.9 & ( \\
\hline 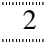 & Electricity & 31.9 & 30.6 & 21.8 & n & 2.8 & no. \\
\hline 3 & Coal and other fuels mining & 26.9 & 66.5 & 19.0 & 18.7 & 22.3 & 7.2 \\
\hline 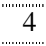 & Transportation & 24.7 & 23.2 & 15.1 & (3.2 & 2.4 & 1.1 \\
\hline " 5 & Agriculture and forestry & 15.4 & 18.2 & 7.2 & 4.4 & 4.1 & 2.9 \\
\hline 6 & Other manufacturing & 14.1 & 20.6 & 12.6 & 2.5 & 2.7 & 2.4 \\
\hline " 7 & Oil processing & 12.3 & 15.9 & 7.0 & 4.7 & 2.8 & 0.3 \\
\hline 8 & Oil extraction & 12.0 & 27.6 & 5.8 & 12.0 & 6.5 & 0.8 \\
\hline 9 & $\begin{array}{l}\text { Machine building and metal } \\
\text { processing }\end{array}$ & 11.3 & 31.8 & 10.5 & 8.5 & 7.1 & 2.7 \\
\hline (1) & Chemical and petrochemical & (11.1.1 & 22.2 & 13.4 & 3.2 & 3.0 & (1.1 \\
\hline 11 & Iron and steel & 10.1 & 19.6 & 10.2 & 3.1 & 3.7 & 1.3 \\
\hline 12 & Non-ferrous metallurgy & 10.0 & 23.6 & 9.4 & 5.4 & 5.9 & 2.8 \\
\hline (13 & Textile, apparel, and footwear & $\begin{array}{l}9 \\
9.0\end{array}$ & 26.8 & 9.8 & 7.1 & 7.2 & 2.2 \\
\hline 14 & Wood and paper & - n & 29.5 & 10.5 & 7.0 & 8.1 & 3.0 \\
\hline 15 & Construction materials & 8. & 15.8 & 7.2 & 3.7 & 3.1 & 1.6 \\
\hline 16 & Construction & 4.2 & 22.2 & 9.4 & 2.7 & 7.1 & 3.5 \\
\hline 17 & Food processing & 2.6 & 5.7 & 2.3 & 1.7 & 1.1 & 0.5 \\
\hline 18 & $\begin{array}{l}\text { Residential and communal } \\
\text { services* }\end{array}$ & & 26.6 & & & & \\
\hline "19um & Communications* & & 3.9 & & 1.1 & & \\
\hline 20 & Trade and food services* & & 2.5 & & & & \\
\hline 21 & Various sectors* & & 2.0 & & 1.2 & & \\
\hline 22 & Health, education, and culture & & & & & & 12.4 \\
\hline 23 & Science & & & & & & 2.8 \\
\hline & Memo: Simple average & 15.7 & 23.7 & 12.1 & 5.6 & 5.6 & 2.7 \\
\hline
\end{tabular}

Sources: GKS 1998a, Table 6.12; 1998b, Tables 3.58-9; 1998e, various tables related to different sectors; 1999 , Table 10.33; and Clarke [1997]. For the sectors with asterisk data on payables are on January 1, 1998. The total payables are larger than the sum of arrears presented in the table because debt owed to other non-financial creditors is omitted.

\footnotetext{
${ }^{38}$ The question was formulated as "Have you received in the last 30 days at this enterprise in lieu of payment for your labor something from its production or from the production of another enterprise?"

${ }^{39}$ Technically, the overdue credit comprises unpaid bills issued more than 3 months ago.
} 
Numbers in Tables,A4 and A5 are aggregates of accounting statements that taxpayers submit to fiscal authorities. ${ }^{40}$ Receivables indicate the share of goods and services delivered to customers prior to the payment. They include both normal trade credit and unpaid bills that will be written off as unrecoverable losses in the end. Payables show how much the reporting firm owes to its suppliers, workers, and the government in unpaid taxes. The nature of firm's creditors is detailed in the balance sheet.

Tables A4 and A5 show that the sectors dominated by the state-controlled monopolies (natural gas, electricity, and railroads) and the sector of coal mining are large creditors to the rest of the economy. This observation is consistent with the claim that the government supports the economy by allowing debtors to accumulate unpaid bills to the first three sectors.

Table A5: Change in arrears in 1997, in percent of sector's revenue for that year.

\begin{tabular}{|c|c|c|c|c|c|c|c|}
\hline & & Receivables & $\begin{array}{c}\text { Total } \\
\text { payables }\end{array}$ & $\begin{array}{c}\text { Trade } \\
\text { arrears }\end{array}$ & $\begin{array}{c}\text { Tax } \\
\text { arrears }\end{array}$ & $\begin{array}{l}\text { Social } \\
\text { Funds } \\
\text { arrears }\end{array}$ & $\begin{array}{l}\text { Wage } \\
\text { arrears }\end{array}$ \\
\hline 1 & "Electricity & 18.7 & 20.0 & 12.1 & 2.4 & 2.6 & 0.3 \\
\hline 2 & Gas extraction & 14.6 & 31.7 & 2.2 & 12.8 & 5.1 & -1.3 \\
\hline 3 & Non-ferrous metallurgy & 8.7 & 8.3 & 4.3 & -0.6 & 2.8 & -0.7 \\
\hline 4 & Coal and other fuels mining & 8.4 & 37.6 & 4.3 & 14.9 & 13.0 & 3.0 \\
\hline 5 & Transportation & 8.0 & 9.0 & 3.6 & 2.8 & 1.3 & -0.1 \\
\hline 6 & $\begin{array}{l}\text { Machine building and metal } \\
\text { processing }\end{array}$ & 4.5 & 15.3 & 4.8 & 4.8 & 4.3 & 0.7 \\
\hline 7 & Iron and steel & 4.1 & 13.7 & 8.0 & 1.8 & 2.3 & 0.3 \\
\hline - & Agriculture and forestry & 4.0 & (3.4 & 2.2 & 2.4 & 2.4 & 0.2 \\
\hline 9 & Construction materials & 3.5 & 9.2 & 3.6 & 2.6 & 2.4 & 0.3 \\
\hline 10 & Other manufacturing & 2.8 & - & 2.6 & 2.5 & 1.2 & 17.7 \\
\hline 111 & Chemical and petrochemical & 2.5 & 10.0 & 5.2 & 2.3 & 1.9 & 0.4 \\
\hline 12 & Textile, apparel, and footwear & 2.0 & 15.1 & 5.2 & 4.3 & 4.4 & 0.5 \\
\hline 13 & Wood and paper & 1.8 & (1) & 3.6 & - n & 5.8 & 0.8 \\
\hline 14 & Food processing & 1.1 & 2.9 & 1.0 & 0.9 & 0.7 & 0.1 \\
\hline 15 & Construction & 1.0 & 14.7 & 4.9 & 2.2 & 6.2 & 1.1 \\
\hline 16 & Oil processing & 0.9 & (2) & 3.4 & 1.5 & 2.5 & -0.2 \\
\hline 17 & Oil extraction & -0.7 & -4.3 & 1.5 & -2.2 & -2.1 & 0.1 \\
\hline 18 & Health, education, and culture & & & & & & -8.6 \\
\hline 19 & "'science & & & & & & 0.3 \\
\hline & Memo: Average & 5.0 & ( 13.0 & 4.3 & 3.5 & 3.4 & 1.2 \\
\hline
\end{tabular}

Sources: GKS 1998a, Table 6.12; 1998b, Tables 3.58-9; 1999, Table 10.33. Clarke [1997]

Another observation appears to contradict the subsidizing nature of this credit because large creditors happen to be large debtors as well. This is a general feature of data reported in Table A4. ${ }^{42}$ Yet, if we assume that nominal prices are not representative of the market value of goods and services, the contradiction disappears.

The changes in the value of receivables and payables that occurred in 1997 are highly correlated with their stock at the beginning of the year (the correlation coefficients are 0.807 and 0.856

\footnotetext{
${ }^{40}$ Taxpayers are obliged to submit separate forms to statistical offices but, even if they comply, the forms provide about the same information as to tax authorities.

${ }^{41}$ Data is found as the residual of total manufacturing minus the sum of its other sub-sectors.

${ }^{42}$ The correlation coefficient for 17 sectors of Table 4, for which total value of receivables and payables is reported, is 0.755
} 
respectively). This observation suggests that the trends in arrears were preserved throughout the year.

\section{Section A2: Accounting Estimates of Barter and Arrears}

Another source of data that we can explore is accounting information that publicly traded companies disclose following the rules set by the Federal Committee on Securities. While the firms are not required to report the value of bartered goods explicitly, it is possible to derive its proxy using indirect indicators. If the value of total revenue is reduced by the sum of money payments and the positive change in receivables throughout the year, the resulting number is a close estimate of the value of barter in sales. The formula that we use is

BarterShareSale $=\operatorname{Max}\left[\operatorname{Min}\left\{100\left(1-\frac{\text { RevenueMoney }+ \text { Max }[\Delta \text { Receivables,0] }}{\text { RevenueTotal }}\right), 100\right\}, 0\right]$

Table A6: Average barter and changes in receivables and payables, 1997 (sorted by the magnitude of barter)

\begin{tabular}{|c|c|c|c|c|c|}
\hline & Sector & $\begin{array}{l}\text { Barter in } \\
\text { sale (\%, } \\
\text { total sales) }\end{array}$ & $\begin{array}{l}\text { Change in } \\
\text { receivables ( } \% \text {, } \\
\text { total sales) }\end{array}$ & $\begin{array}{l}\text { Change in } \\
\text { payables }(\% \text {, } \\
\text { total costs) }\end{array}$ & $\begin{array}{c}\text { Number of } \\
\text { observations }\end{array}$ \\
\hline 1 & Coal mining & 73.8 & 11.3 & 35.7 & 54 \\
\hline 2 & Ferrous metallurgy & 69.3 & 12.8 & 20.0 & 83 \\
\hline (3) & Petrochemical & 68.8 & 13.3 & 24.3 & 44 \\
\hline " & Construction materials & 64.5 & 12.2 & 26.6 & 152 \\
\hline 5 & Oil processing & 64.1 & 5.4 & 6.5 & 21 \\
\hline - & Automotive & 61.6 & 11.6 & 38.2 & 130 \\
\hline 7 & Processing equipment & 58.9 & 12.4 & 35.5 & 91 \\
\hline 8 & Heavy machinery & 57.4 & 10.8 & 28.0 & 143 \\
\hline "'m"' & Electricity & 56.6 & 23.3 & 34.4 & 92 \\
\hline 10 & Preserves & 52.7 & 5.1 & 14.5 & 45 \\
\hline 11 & Textiles & 52.1 & 8.5 & 17.4 & 114 \\
\hline 12 & Chemical & 51.2 & 10.2 & 28.0 & 89 \\
\hline 13 & Electric equipment & 49.2 & 14.9 & 27.4 & 186 \\
\hline 14 & Leather and footwear & 48.5 & 6.3 & 24.7 & 50 \\
\hline 15 & Non-ferrous metallurgy & 48.2 & 6.8 & 17.4 & 58 \\
\hline 16 & Oil extraction & 46.6 & 11.7 & 27.4 & 36 \\
\hline 17 & Glass and porcelain & 44.8 & 6.0 & 21.3 & 22 \\
\hline 18 & Wood and paper & 44.5 & 9.7 & 28.0 & 130 \\
\hline 19 & Ship and aircraft building & 44.5 & 20.7 & 65.6 & 68 \\
\hline 20 & Gas extraction & 43.4 & 12.7 & 32.5 & 12 \\
\hline 21 & Butter, milk, and oil & 40.3 & 2.9 & 6.3 & 84 \\
\hline 22 & Agriculture and forestry & 39.9 & 8.6 & 25.4 & 172 \\
\hline 23 & Construction & 39.6 & 21.1 & 29.9 & 301 \\
\hline 24 & Sugar and confectionery & 36.5 & 4.5 & 8.8 & 60 \\
\hline 25 & Financial management & 33.0 & 22.7 & 35.9 & 41 \\
\hline 26 & Science and geology & 32.0 & 18.8 & 27.9 & 127 \\
\hline 27 & Apparel & 31.4 & (13.1 & 28.1 & 59 \\
\hline 28 & Other industries & 30.2 & 16.3 & 13.7 & 70 \\
\hline 29 & Various sectors & 29.7 & 29.8 & 20.8 & 16 \\
\hline 30 & Meat processing & 27.7 & 4.1 & 7.9 & 45 \\
\hline 31 & Trade services & 26.1 & 16.4 & 20.2 & 138 \\
\hline 32 & Transportation & 23.6 & 11.8 & 13.0 & 186 \\
\hline 33 & Medical and cultural services & 21.2 & 8.7 & 20.1 & 50 \\
\hline 34 & Bread and other grains & 21.0 & 3.5 & 5.5 & 117 \\
\hline
\end{tabular}




\begin{tabular}{|c|c|c|c|c|c|}
\hline 35 & Residential services & 17.4 & 29.2 & 27.4 & 65 \\
\hline 36 & 'Retail and wholesale trade & 11.6 & 9.7 & 15.4 & 219 \\
\hline 37 & Telecommunications & 10.6 & 9.5 & 10.2 & (a) \\
\hline 38 & Liquors, water, and tobacco & 10.1 & 16.0 & 40.0 & 84 \\
\hline & $\begin{array}{l}\text { Memo: Simple average and number of } \\
\text { observations }\end{array}$ & 41.6 & 12.4 & 23.9 & 3,553 \\
\hline
\end{tabular}

Source: Author's sample and calculations. Observations with the change in arrears for more than 500 of total revenue (total costs) have been excluded from the consideration as outlays.

Data on arrears are reported explicitly and we find their share using the formula

$$
\text { ArrearsShareX }=100\left(\frac{\Delta \text { Arrears }}{X}\right)
$$

where $\mathrm{X}$ stands for the total revenue or costs depending on what arrears we measure: receivables or payables.

Total revenue is reported in line 10 of the Financial Statement, line 30 of the Report on Money Transactions provides the value of money received for supplied goods and services, and numbers for long and short-term receivables at the beginning and the end of the year appear in lines 230 and 240 of the Balance Sheet. The stock and the change in long and short-term receivables and payables are reported in the Balance Sheet, lines 230, 240, and 620. We report the ratios of the change in receivables to total revenue and the change in payables to the total costs. The latter is presented in line 20 of the Financial Statement.

We have collected accounting and financial information for 3,605 Russian companies for 1997

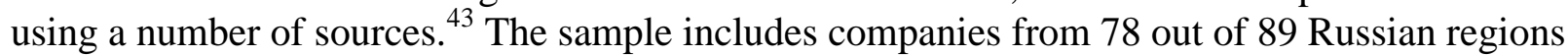
and represents a large variety of sectors. For the purpose of presentation, we divide the sample in 38 groups that loosely comply with the industrial classification OKONKh.

Table A6 shows the results that are similar to what other tables present. This finding suggests that accounting information can provide us with reliable data on non-monetary exchanges.

\footnotetext{
${ }^{43}$ Total number does not correspond with Table A6 because some observations are missing. The main source is the database supported by NAUFOR that is accessible at http://www.skrin.ru. The author expresses his gratitude to Alexander Sumtsov for allowing to use the database. Other sources include regional offices of the Federal Committee for Securities in Moscow, Rostov, and Ufa.

${ }^{44}$ See the Russian State Committee for Statistics "All-Union Industrial Classification of National Economy" (OKONKh), Publication 1-75-018, Moscow, January 1, 1976
} 


\section{Appendix B: The Methodology and Data Sources for Price Conversion}

We use the input-output table for 1997 as our starting point (see GKS [2000b, Table 4.4]). Since the table contains 10 sectors only and aggregates the most important sectors of mining and manufacturing, the table should be expanded. We disaggregate the sector of mining and manufacturing into fourteen sectors. In addition, sectors of transport and communications, and banking and management are divided into four sectors with obvious names. .5

Determining values for missing sectors, we follow the procedure that input-output designers usually use. At first, we find total values on costs and revenue. Then we calculate individual cost parameters that sum up to the totals and have the same structure as a base matrix of costs.

Numbers on total output, the value-added, intermediate costs, labor compensation, and indirect taxes for transport, communications, banking, and management come from GKS [2000b, Table 2.13 and 2.25] and we put them in the respective cells of the table. For sub-sectors of mining and manufacturing, total values are not reported in the system of national accounts. We take numbers on the output from the input-output table for 1995 instead (GKS [2000a, Table 4.1]) and adjust them to 1997. The indices of output change in physical units for 1996 and 1997 (GKS [1998a, table 1.9] and the indices of price changes for the same years (GKS [1998a, table 8.1 and 8.4] are used for adjustment

$$
\text { Output }_{97}=\left(\text { Index }_{96} \text { IndexP }_{96}\right)\left(\text { Index }_{97} \text { IndexP }_{97}\right) \text { Output }_{95}
$$

where Index $Q_{\text {year }}$ is the index of the change in output in physical units and IndexP $P_{\text {year }}$ is the index of the change in prices for the year.

The labor expenses for 1997 are found as a ratio of the ratios of labor cost shares to revenues for 1997 and 1995 times labor expenses taken from the input-output table for 1995. Data on the shares of wage bill and social contributions are from GKS [1998a, Table 7.6] and on the return on costs - from GKS [1998b, Table 3.11]

$$
\text { Labor }_{97}=\left(\frac{\left[\text { WageShare }_{97}+\text { SocialFeeShare }_{97}\right] / \text { Revenue }_{97}}{\left[\text { WageShare }_{95}+\text { SocialFeeShare }_{95}\right] / \text { Revenue }_{95}}\right) \text { Labor }_{95}
$$

Gross profits are found similarly with the profit representing the return on costs plus depreciation ${ }^{46}$

$$
\text { GrossProfit }_{97}=\left(\frac{\left.\left[\text { (Revenue }_{97} / \text { Cost }_{97}-1\right)+\text { Depreciation }_{97}\right] / \text { Revenue }_{97}}{\left.\left[\text { Revenue }_{95} / \text { Cost }_{95}-1\right)+\text { Depreciation }_{95}\right] / \text { Revenue }_{95}}\right) \text { GrossProfit }_{95} \quad[B 2 a]
$$

We assume that the distribution of mixed profit among industries is identical in structure to the values reported in the input-output table for 1995. Indirect taxes are divided according to the structure of tax collection for 1997 as reported CEC [1998]. The sector of textile and footwear is assumed to stay as the only recipient of subsidies allocated to manufacture in 1997 . The valueadded at producer's price represents the sum of labor compensation, profits, and net indirect taxes, while the cost of intermediate products is the difference between the total output and the value-added.

\footnotetext{
${ }^{45}$ The last four sectors are not necessary for our analysis since we do not find its price ratios. We follow the procedure used to construct the input-output table for 1995 that contains 25 sectors (see Ivanenko [2001]).

${ }^{46}$ The depreciation is equal to the capital cost allowances.
} 
After horizontal rows of aggregate numbers for total output are filled, we proceed with vertical rows of aggregate numbers for consumption. To arrive at numbers for intermediate consumption, we subtract net export, final consumption by households, government and NGO, and changes in inventories from the total domestic output. For export (and import), we use the ratio of reported values for 1995 and 1997 (see GKS [1996, Table 357 and 1998c, Tables 3.5, 3.7, and 3.9]) times the value from the input-output table for 1995

$$
\text { Export }_{97}=\frac{\text { ExportValue }_{97}}{\text { ExportValue }_{95}} \text { Export }_{95}
$$

The change of inventories for producers is from data on the stock of finished products in GKS [1998a, Table 1.15] apart from the sectors of fuels and other manufacturing. The latter are found by dividing the residual of the total value according to the weights of sectors in the inventories for the input-output table 1995. The change in inventories for consumers is found as the matrix multiplication of the costs of production from the input-output table for 1995 times the changes in the stock of intermediate goods from GKS [1998a, Table 7.7] excluding fuels. The latter sectors are found as the change in physical inventories (see GKS [1998c, Table 2.63]) times average prices for fuels from GKS [1998d, Table 4.11]. We assume that the change of inventories for traders follows the same pattern as reported in the input-output table for 1995 . Similarly, the final consumption preserves the same pattern of 1995.

Table B1: Input-output table for 1997 updated using I/O 1997, in billion of rubles

\begin{tabular}{|c|c|c|c|c|c|c|c|c|}
\hline & 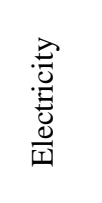 & 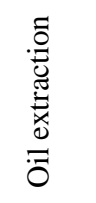 & 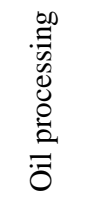 & 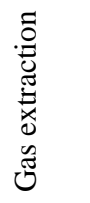 & 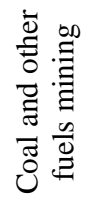 & 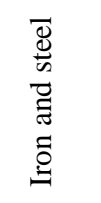 & 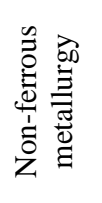 & 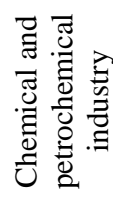 \\
\hline Electricity & 8,911 & 13,328 & 3,903 & 9,011 & 3,878 & 13,439 & 8,803 & 24,222 \\
\hline Oil extraction & 57 & 549 & 63,084 & (") & 0 & (") & 0 & 730 \\
\hline Oil processing & 5,064 & 1,174 & 1,650 & 2,052 & 432 & 1,634 & 2,178 & 2,958 \\
\hline Gas extraction & 16,921 & 0 & 0 & 1,402 & 0 & 1,582 & 335 & 2,480 \\
\hline Coal and other fuels mining & 10,476 & "30 & 69 & 72 & 3,310 & 10,182 & 447 & 574 \\
\hline Iron and steel & 727 & 222 & 221 & 229 & 612 & 32,437 & 2,522 & 2,975 \\
\hline Non-ferrous metallurgy & 404 & 31 & 31 & 32 & 1 & 1,252 & 14,220 & 390 \\
\hline Chemical and petrochemical & 1,179 & 679 & 676 & 700 & 1,423 & 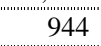 & 2,411 & 26,839 \\
\hline Machine building and metal processing & "'"4,913 & 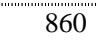 & 856 & "'s" & 2,801 & "' 4," & 3,757 & 3,051 \\
\hline Wood and paper & 98 & 28 & 27 & 28 & 334 & 249 & 371 & 1,412 \\
\hline Construction materials & 238 & 34 & 33 & 35 & 138 & 280 & 185 & 523 \\
\hline Textile, apparel, and footwear & 1 & 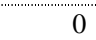 & "ln & ("'me & 1 & 3 & 1 & "“? \\
\hline Food processing & 21 & 5 & 5 & 5 & 12 & 23 & 28 & 451 \\
\hline Other manufacturing & 547 & 132 & 131 & 136 & 110 & 345 & 213 & 583 \\
\hline Construction & 541 & 254 & 253 & 262 & 204 & 655 & 670 & 573 \\
\hline Agriculture and forestry & 0 & 3 & 3 & 3 & 0 & 9 & 3 & 20 \\
\hline Transportation & 28,782 & (1,914 & 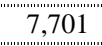 & 2,130 & 2,778 & (13,482 & 3,321 & 9,011 \\
\hline Communications & 228 & 592 & 588 & 610 & 860 & 281 & 322 & 547 \\
\hline Trade, intermediation, and food services & 13,985 & 609 & 3,864 & 975 & 1,452 & 7,751 & 4,695 & 5,412 \\
\hline $\begin{array}{l}\text { Other activities related to goods and } \\
\text { services }\end{array}$ & 648 & 233 & 232 & 240 & 276 & 776 & 450 & 556 \\
\hline $\begin{array}{l}\text { Residential, communal, and household } \\
\text { services }\end{array}$ & 170 & 103 & 103 & 107 & 128 & 93 & 144 & 152 \\
\hline
\end{tabular}




\section{William Davidson Institute Working Paper 428}

\begin{tabular}{|c|c|c|c|c|c|c|c|c|}
\hline & 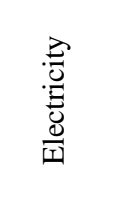 & 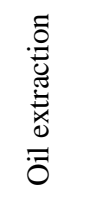 & 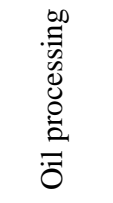 & 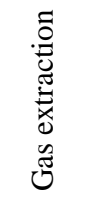 & 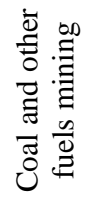 & 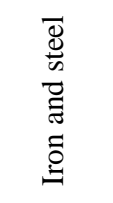 & 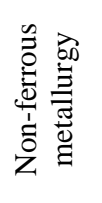 & 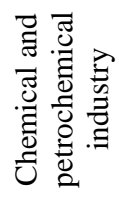 \\
\hline Health, education, and culture & 20 & 19 & 19 & 20 & 32 & 12 & 16 & 25 \\
\hline Science, geology, and meteorology & 187 & 1,049 & 1,043 & 1,081 & 56 & 1,009 & 81 & 1,600 \\
\hline Finance, credit, and insurance & 317 & 263 & 262 & 271 & 179 & 148 & 317 & 228 \\
\hline $\begin{array}{l}\text { State and business management and } \\
\text { NGO }\end{array}$ & 184 & 153 & 152 & 158 & 104 & 86 & 184 & 133 \\
\hline $\begin{array}{l}\text { Total intermediate consumption by } \\
\text { sector }\end{array}$ & 94,620 & 22,304 & 84,907 & 20,447 & 19,120 & 90,701 & 45,673 & 85,453 \\
\hline Labor expenses & 27,296 & 9,544 & 8,706 & 3,009 & 11,165 & 18,341 & 17,148 & 19,005 \\
\hline Gross profit & 65,697 & 45,349 & 24,914 & 28,848 & 7,000 & 11,702 & 22,079 & 4,822 \\
\hline Net taxes on material inputs and output & 18,325 & 17,452 & 23,899 & 8,180 & 4,465 & 623 & 6,529 & 8,069 \\
\hline Value-added at producer's price & 102,471 & 71,677 & 36,097 & 38,713 & 20,658 & 32,474 & 43,123 & 26,925 \\
\hline Total output & 205,939 & (9) & 142,428 & 60,483 & 41,751 & 121,367 & 91,430 & 117,349 \\
\hline
\end{tabular}

Sources: GKS 1996, Table 357; 1998a, Tables 1.9, 1.15, 7.6, 7.7, 8.1, 8.4; 1998b, Tables 3.11, 3.23, 3.26; 1998c,

Tables 2.63, 3.5, 3.7, 3.9; 1998d, Table 4.11; 2000a, Table 4.1; 2000b, Tables 2.13, 2.25, 4.4; CEC [1998, Table 9], Ivanenko [2001]. Numbers in bold are original numbers from GKS [2000a, Table 4.4], numbers in italics are from other original sources, numbers in plain font are author's calculations.

Table B1 (continued ...)

\begin{tabular}{|c|c|c|c|c|c|c|c|c|}
\hline & 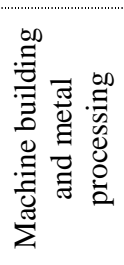 & 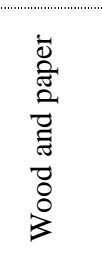 & 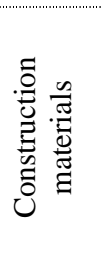 & 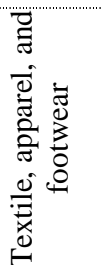 & 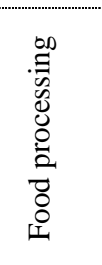 & 离 & 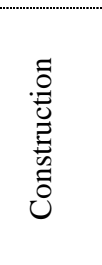 & 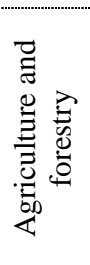 \\
\hline Electricity & 22,374 & 6,191 & (9,527 & 3,333 & 6,561 & (3,443 & 3,213 & 5,639 \\
\hline Oil extraction & 0 & 0 & 202 & (n) & 0 & - & 960 & -0 \\
\hline Oil processing & 3,820 & 2,993 & 2,097 & 372 & 7,236 & 513 & 8,519 & 9,803 \\
\hline Gas extraction & 633 & (n) & (1,132 & 158 & 0 & - n & 0 & 1,239 \\
\hline Coal and other fuels mining & 1,126 & 473 & 392 & 289 & 819 & 153 & 682 & 649 \\
\hline Iron and steel & 25,684 & 660 & 3,772 & 162 & 897 & 542 & 14,495 & 152 \\
\hline Non-ferrous metallurgy & 4,978 & 122 & 206 & 6 & 384 & 1,428 & 347 & 0 \\
\hline Chemical and petrochemical & "' 8,368 & 2,529 & 1,956 & "'m,919 & 2,972 & 2,050 & 4,732 & 8,730 \\
\hline Machine building and metal processing & 62,423 & 2,947 & 1,688 & 814 & 6,127 & 1,002 & 24,084 & 12,227 \\
\hline Wood and paper & 1,726 & 14,571 & 825 & 174 & 4,259 & 2,126 & 5,267 & 306 \\
\hline Construction materials & 673 & 255 & 8,422 & 52 & 792 & 93 & 45,817 & 959 \\
\hline Textile, apparel, and footwear & 7 & " & 3 & 252 & 11 & 12 & 3 & 5 \\
\hline Food processing & 58 & 25 & 8 & 125 & 52,877 & 869 & 29 & 7,019 \\
\hline Other manufacturing & 774 & 116 & 179 & 157 & 1,794 & 2,490 & 216 & 10,041 \\
\hline Construction & 587 & 230 & 368 & 127 & 1,657 & 183 & 1,385 & 1,147 \\
\hline Agriculture and forestry & 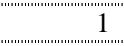 & "lon & (3) & 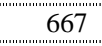 & $\begin{array}{ll}58,857 \\
5\end{array}$ & - la & 1 & 87,240 \\
\hline Transportation & 8,246 & 4,725 & 6,435 & 1,671 & 9,033 & 1,579 & 23,628 & 9,642 \\
\hline Communications & 678 & 353 & 320 & "170 & 888 & 150 & 1,962 & 1,278 \\
\hline Trade, intermediation, and food services & (13,777 & 3,068 & 2,962 & 4,282 & 19,922 & 1,289 & 23,185 & 13,266 \\
\hline $\begin{array}{l}\text { Other activities related to goods and } \\
\text { services }\end{array}$ & 1,257 & 211 & 337 & 400 & 1,049 & 401 & 787 & 146 \\
\hline $\begin{array}{l}\text { Residential, communal, and household } \\
\text { services }\end{array}$ & 437 & 105 & 98 & 165 & 527 & 68 & 1,077 & 561 \\
\hline Health, education, and culture & (36 & 14 & 10 & 13 & 65 & 16 & 61 & 34 \\
\hline Science, geology, and meteorology & 4,451 & 12 & 17 & 15 & 75 & (3)" & 874 & 416 \\
\hline
\end{tabular}




\begin{tabular}{|c|c|c|c|c|c|c|c|c|}
\hline & 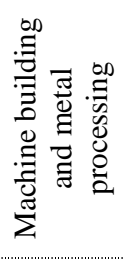 & 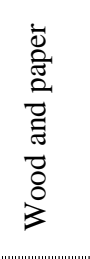 & 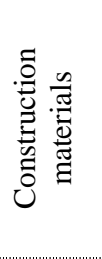 & 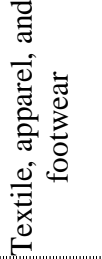 & 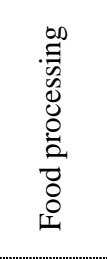 & 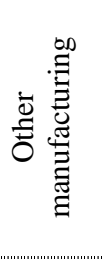 & 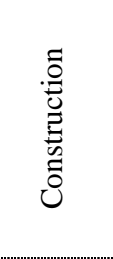 & 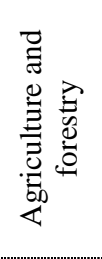 \\
\hline Finance, credit, and insurance & 755 & 165 & 115 & 212 & 1,052 & 85 & 1,162 & 105 \\
\hline $\begin{array}{l}\text { State and business management and } \\
\text { NGO }\end{array}$ & 439 & 96 & 67 & 123 & 612 & 50 & 419 & 115 \\
\hline $\begin{array}{l}\text { Total intermediate consumption by } \\
\text { sector }\end{array}$ & 163,308 & 39,869 & 41,136 & 18,658 & 178,467 & 22,194 & 162,906 & 170,718 \\
\hline Labor expenses & 73,147 & 16,914 & 14,030 & 9,101 & 27,683 & 10,724 & 99,259 & 43,593 \\
\hline Gross profit & 38,341 & 2,041 & 12,408 & 6,962 & 42,448 & 3,231 & 67,067 & 105,572 \\
\hline Net taxes on material inputs and output & 17,146 & 2,985 & 4,048 & $-3,116$ & 4,159 & 5,172 & 19,498 & $\begin{array}{ll}2,682 \\
2,63\end{array}$ \\
\hline Value-added at producer's price & 124,254 & 21,018 & 28,695 & 12,399 & 83,103 & 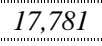 & 179,200 & 149,269 \\
\hline Total output & 291,945 & 61,810 & 71,622 & 31,604 & 252,751 & 41,320 & 348,730 & 322,565 \\
\hline
\end{tabular}

After the numbers for the sums of the rows and columns are determined, we use RAS procedure to update the input-output table for 1995 to 1997. The procedure is explained in UN [1999] and it is generally used if an input-output table is unavailable for a particular year. We take the variant of the table developed for Ivanenko [2001]. It contains 25 sectors (see Table B1). Finally, banking margin is divided among all sectors taking the data on credits and loans (see GKS [1998b, Table 3.23 and 3.26]) as proxies for sectoral credit rates. We add the margin to the cost of banking services, while transportation and trade margins are added to the intermediate costs of transportation and trade. The table and its constituent parts are shown below.

Having constructed the input-output table, we proceed with finding price conversion rates. We take Russian producer's prices from GKS [1998d, Table 4.11 and 6.8]. Since there is no reported numbers for the sector of other manufacturing, we take consumer's prices for six items belonging to the group GKS [1998d, Table 2.20]. ${ }^{47}$ The prices for few missing products are deducted in various ways. For bailed hay, the price is from the publication "Methods of calculating pure income in dairy farming" taken as the ratio of the suggested prices for hay and animal feed times the price of animal feed for 1997.

\footnotetext{
${ }^{47}$ Transportation and trade margins plus net direct taxes might make consumer's prices higher than producer's but we discount this possibility for the group because we have no proxies to adjust the numbers. Besides, the US prices are taken from commercial sources representing consumer prices apart from publishing.

${ }^{48}$ See http://www.aris.krasnodar.ru/metodika2/met2_14.htm
} 


\section{William Davidson Institute Working Paper 428}

Table B1 (continued ...)

\begin{tabular}{|c|c|c|c|c|c|c|c|c|}
\hline & 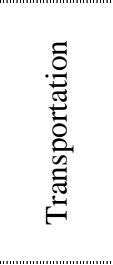 & 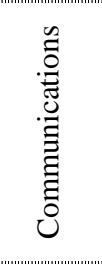 & 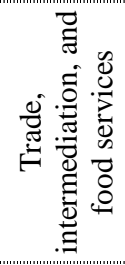 & 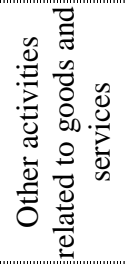 & 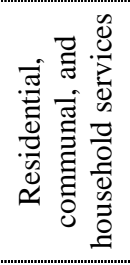 & 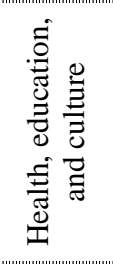 & 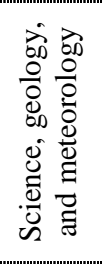 & 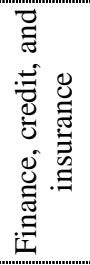 \\
\hline Electricity & 20, & 665 & (5,770 & 154 & $\begin{array}{l}12,431 \\
13\end{array}$ & 4,845 & 955 & 715 \\
\hline Oil extraction & 0 & 0 & 0 & lo & 0 & 0 & 54 & 0 \\
\hline Oil processing & 20,030 & (3,352 & (3) & 233 & 22,732 & 3,167 & $\begin{array}{ll}1,998 \\
1,3\end{array}$ & 1,170 \\
\hline Gas extraction & - n & 0 & (n) & - ne & 892 & (3) & 0 & (3) \\
\hline Coal and other fuels mining & 625 & 32 & 917 & 12 & 4,455 & 1,837 & 45 & 274 \\
\hline Iron and steel & 3,511 & 237 & 682 & 20 & 3,763 & 439 & 630 & .2. \\
\hline Non-ferrous metallurgy & 33 & 9 & 11 & (3) & 25 & (3) & 100 & - \\
\hline Chemical and petrochemical & 2,642 & 711 & 6,006 & 75 & 3,238 & 21,347 & 2,507 & 471 \\
\hline Machine building and metal processing & 15,294 & 3,450 & 14,806 & 690 & 9,531 & 10,547 & 5,410 & 3,052 \\
\hline Wood and paper & 1,062 & 289 & 6, 6, & 2,418 & 629 & 2,556 & 344 & 370 \\
\hline Construction materials & 1,422 & 385 & 4,508 & 19 & 4,376 & 2,217 & 213 & 19 \\
\hline Textile, apparel, and footwear & 10 & 3 & 32 & 1 & 11 & 56 & 1 & 7 \\
\hline Food processing & 174 & 46 & 8,270 & 20 & 201 & 19,132 & 90 & 1,011 \\
\hline "' Other manufacturing & 716 & 196 & 1,814 & 1,785 & 4,833 & 3,427 & 286 & 602 \\
\hline Construction & 2,295 & 326 & $\mathbf{7 , 1 4 6}$ & 160 & 7,177 & $\mathbf{5 , 0 8 4}$ & 854 & 672 \\
\hline Agriculture and forestry & 0 & (1) & $5, \mathbf{5}-198$ & 1 & 189 & $\mathbf{3 , 5 9 8}$ & 79 & 736 \\
\hline Transportation & (13,442 & 1,883 & 30,135 & 1,144 & 13,066 & 9,603 & 2,318 & (3,196 \\
\hline Communications & 3,197 & (3) & (8,627 & (3) & 580 & 2,152 & 508 & 877 \\
\hline Trade, intermediation, and food services & 27,378 & (3) & 32,958 & 939 & 8,507 & 13,785 & 1,076 & 2,041 \\
\hline $\begin{array}{l}\text { Other activities related to goods and } \\
\text { services }\end{array}$ & 1,229 & 175 & 8,061 & 950 & 479 & 2,738 & 263 & 430 \\
\hline $\begin{array}{l}\text { Residential, communal, and household } \\
\text { services }\end{array}$ & 2,099 & 299 & 6,781 & 225 & 3,177 & 25,555 & 636 & 4,142 \\
\hline Health, education, and culture & 115 & 16 & 427 & 26 & 38 & 826 & 12 & 43 \\
\hline Science, geology, and meteorology & 3,282 & 407 & 1,657 & (35 & 254 & 91 & 15,600 & 661 \\
\hline Finance, credit, and insurance & - & 160 & 1,981 & (3) & 540 & 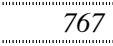 & 150 & 376 \\
\hline $\begin{array}{l}\text { State and business management and } \\
\text { NGO }\end{array}$ & 1,157 & 165 & 2,918 & 80 & 340 & 519 & 101 & 740 \\
\hline $\begin{array}{l}\text { Total intermediate consumption by } \\
\text { sector }\end{array}$ & 120,877 & 17,214 & 171,241 & 9,373 & 101,462 & 134,302 & 34,229 & 21,610 \\
\hline Labor expenses & 92,641 & 19,941 & 70,656 & 8,606 & 54,527 & 127,314 & 26,043 & 22,547 \\
\hline Gross profit & 117,015 & $\mathbf{2 0 , 5 2 4}$ & 407,232 & 10,099 & 77,264 & 62,898 & 1,306 & $-8,164$ \\
\hline Net taxes on material inputs and output & 32,604 & 5,005 & 21,896 & 1, 125 & $\begin{array}{l}8,322 \\
8,322\end{array}$ & 9,9355 & 3,933 & 4,003 \\
\hline Value-added at producer's price & 233,421 & 44,213 & 494,837 & 19,667 & 133,620 & 191,707 & 28,543 & 16,493 \\
\hline Total output & $\mathbf{3 6 3 , 1 3 7}$ & 62,685 & 671,025 & 29,203 & 241,575 & 333,869 & 65,511 & 39,995 \\
\hline
\end{tabular}


Table B1 (continued ...)

\begin{tabular}{|c|c|c|c|c|c|c|}
\hline & 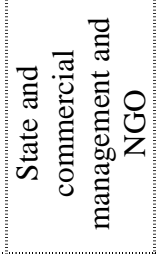 & 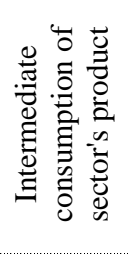 & 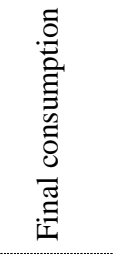 & 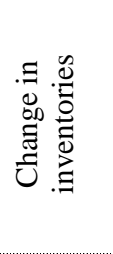 & 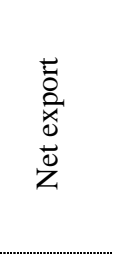 & 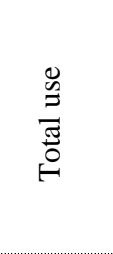 \\
\hline Electricity & (4, & 196,066 & 7,710 & 0 & 2,178 & 205,955 \\
\hline Oil extraction & 0 & 65,636 & 59 & 0 & 28,954 & 94,650 \\
\hline Oil processing & 7,606 & 128,492 & 4,447 & 992 & 8,497 & 142,428 \\
\hline Gas extraction & - n la & 27,770 & $\begin{array}{ll}558 \\
558\end{array}$ & -724 & 32,870 & 60,474 \\
\hline Coal and other fuels mining & 1,777 & 39,756 & 759 & 215 & 1,022 & 41,752 \\
\hline Iron and steel & (n) & (2) & 96 & 3,180 & 22,496 & 121,378 \\
\hline Non-ferrous metallurgy & (n) & 24,030 & 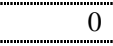 & 9,270 & 58,127 & 91,427 \\
\hline Chemical and petrochemical & 3,053 & 111,159 & 13,063 & 5,649 & $-12,522$ & 117,349 \\
\hline Machine building and metal processing & 24,479 & 219,724 & 50,518 & 117,956 & $\begin{array}{l}-96,253 \\
-96,253\end{array}$ & 291,946 \\
\hline Wood and paper & 2,401 & 48,697 & 11,293 & 4,914 & $-3,094$ & 61,810 \\
\hline Construction materials & 126 & 71,812 & 4,161 & 943 & $-5,294$ & 71,622 \\
\hline Textile, apparel, and footwear & 44 & 480 & $\begin{array}{l}91,071 \\
91,071\end{array}$ & 3,263 & $\begin{array}{l}-63,209 \\
-63\end{array}$ & 31,604 \\
\hline Food processing & 6,557 & (9) & 217,299 & 11,923 & $-73,477$ & 252,807 \\
\hline Other manufacturing & 3,907 & 35,529 & 4,648 & 4,737 & $-3,594$ & 41,320 \\
\hline Construction & 4,847 & 37,657 & 7,911 & $\mathbf{3 0 7 , 2 7 7}$ & $-4,115$ & $\mathbf{3 4 8 , 7 3 0}$ \\
\hline Agriculture and forestry & $\begin{array}{ll}5,316 \\
5,316\end{array}$ & 165,566 & 155,618 & 9,885 & $\begin{array}{l}-8,463 \\
-8,463\end{array}$ & 322,606 \\
\hline Transportation & 23,065 & 231,930 & 78,476 & 5,575 & 47,156 & 363,136 \\
\hline Communications & 6,331 & (32,817 & 24,216 & 辛 & 5,650 & 62,683 \\
\hline Trade, intermediation, and food services & 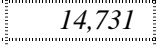 & $\mathbf{2 2 5 , 8 0 5}$ & $\begin{array}{l}301,370 \\
30\end{array}$ & 16,324 & 127,534 & 671,033 \\
\hline $\begin{array}{l}\text { Other activities related to goods and } \\
\text { services }\end{array}$ & 3,107 & 25,432 & 4,639 & 680 & $-1,550$ & 29,201 \\
\hline $\begin{array}{l}\text { Residential, communal, and household } \\
\text { services }\end{array}$ & 29,896 & 76,848 & 164,510 & $\mathbf{0}$ & 219 & 241,577 \\
\hline Health, education, and culture & 310 & 2,226 & 332,354 & o & -712 & 333,868 \\
\hline Science, geology, and meteorology & 4,769 & 38,828 & $\begin{array}{ll}16,702 \\
16\end{array}$ & 11,684 & $-1,708$ & 65,506 \\
\hline Finance, credit, and insurance & 2,781 & 13,457 & 26,757 & $\mathbf{0}$ & -219 & 39,994 \\
\hline $\begin{array}{l}\text { State and business management and } \\
\text { NGO }\end{array}$ & 5,343 & 14,436 & 314,905 & $\mathbf{0}$ & $-1,796$ & $\mathbf{3 2 7 , 5 4 5}$ \\
\hline $\begin{array}{l}\text { Total intermediate consumption by } \\
\text { sector }\end{array}$ & 156,029 & & & & & \\
\hline Labor expenses & 117,955 & & & & & \\
\hline Gross profit & 39,295 & & & & & \\
\hline Net taxes on material inputs and output & 14,263 & & & & & \\
\hline Value-added at producer's price & 157,858 & & & & & \\
\hline Total output & 327,542 & & & & & \\
\hline
\end{tabular}

The price for wall and floor tiles is from the data on the cost of construction materials for construction purposes adjusted by using the price of brick (see GKS [1998d, Table 5.8]). The price of pulp is connected to the producer's price of paper through the ratio of export prices of pulp and paper. Several prices are from commercial reports of various Russian companies that are assumed to be representative. ${ }^{49}$ The prices of methanol and ammonia for three months of

\footnotetext{
${ }^{49}$ The list of prices contains peat, anthracite, lignite, refractory, ductile iron castings, ferrosilicon, gold, silver, raw diamonds, carbon black, equipment coatings, printing ink, protective footwear, rubber products, ball bearings, welders, switches for electrical circuitry transformers, diodes and rectifiers, electric lighting fixtures, concrete sewer pipe, tableware, manmade silk fabrics, leather handbags, and canned milk.
} 
1997 are from the journal "Prices on Russian Market" published by NIIEMPEX. ${ }^{0}$ In total we get a sample of 232 products, which is close to the mark of 256 that Ark and Timmer [2001, Section 3.4] considers sufficient for a comparison of manufacturing.

As a rule, American prices are found as the ratio of the total value divided by the output in physical units. We use for manufacturing and utilities data reported by the Bureau of Census in Current Industrial Reports for 1997 and Census Series EC97. For agriculture data are from Statistical Reports, historical data by the Department of Agriculture and for minerals - from U.S. Geological Survey published by U.S. Department of the Interior. Some missing numbers are taken from trade catalogs or financial reports of large companies. ${ }^{1-}$ The prices of peat, raw diamonds, live fish, and buckwheat are from Canadian data reported by Statistics Canada and converted in the US Dollars at the market exchange rate. Since American producer's prices are unavailab/e for irons, sunflower oil, and buckwheat meal, we take prices for close analogues instead. The list of sampled goods is presented in Table B2.

To convert American units into Russian units of measurement, we use a number of formal and informal sources. For example, data on the size of hide in decimeters, density of painting, weights of bushels of grains and fruits are taken from commercial reports. Tables used by the US Bureau of Census, Department of Energy, Ecological Service, US custom officials were helpful as well.

Products are aggregated in 15 groups using Russian industrial classification OKONKh. We take the ratio of the value of a product in the US Dollars to the total value of sampled goods of a sector as the weight and find the price ratio PriceRatio $i$ for sector $I$ as the ratio of Russian to American prices. After simplifications, the formula for the exchange rate becomes

$$
\text { PriceRatio }_{I}=\frac{\sum_{j \in J} \text { Price }_{j}^{\text {Rus }} \times \text { Output }_{j}^{\text {Rus }}}{\sum_{j \in I} \text { Price }_{j}^{U S} \times \text { Output }_{j}^{\text {Rus }} \times \text { Factor }_{j}}
$$

where Factor $_{j}$ is the conversion factor that accounts for difference in the unit of measurement. Russian output comes mostly from GKS [1998a, Section 11, different tables] but several entries are not available at that source. We use regional data reported by the Russian Ministry of Agriculture, Mineral Group regarding mining, and data from commercial analytical reports to fill the gaps.

Since we ignore Russian prices completely as being unrepresentative of market exchanges, weights do not include a combination of US output measured in Russian prices along with its opposite as it is usually is done in two-country comparative studies.

\footnotetext{
${ }^{50}$ Available at http://master.chemforum.ru/

${ }^{51}$ The list of prices obtained from informal sources contains polyethylene, polyester, ethylene, methanol, roofing paper, structural concrete, linoleum, dresses and other apparel, books and pharmaceuticals.

${ }^{52}$ Waffle irons, canola oil, and bulgur flour.

${ }^{53}$ See http://dbase.aris.ru/N/WIN_R/INFO/STAT/REG/REG_12_98/ supported by the Ministry of Agriculture and http://www.mineral.ru/publication.html for minerals
} 


\section{William Davidson Institute Working Paper 428}

Table B2: Average annual prices for 1997 and price ratio for the sample of products

\begin{tabular}{|c|c|c|c|c|c|c|c|c|}
\hline & Product name in English & $\begin{array}{l}\text { Sector } \\
\text { code }\end{array}$ & $\begin{array}{l}\text { Unit in the } \\
\text { US }\end{array}$ & $\begin{array}{l}\text { Unit in } \\
\text { Russia }\end{array}$ & $\begin{array}{c}\text { Price of US } \\
\text { unit, } \$ 1\end{array}$ & $\begin{array}{l}\text { Price of Russian } \\
\text { unit, } 1,000 \text { rubles }\end{array}$ & $\begin{array}{l}\text { Conversion } \\
\text { factor }\end{array}$ & $\begin{array}{l}\text { Price ratio, } \\
\text { ruble/\$ }\end{array}$ \\
\hline 1 & Electricity & ELE & $1,000 \mathrm{~kW}-\mathrm{H}$ & $1,000 \mathrm{~kW}-\mathrm{H}$ & 77.0 & 249 & 1 & 3,237 \\
\hline 2 & Crude petroleum & OIL & $\mathrm{Bbl}$ & Ton & 17.8 & 368 & 7.5 & 2,765 \\
\hline 3 & Motor gasoline & OIP & $\mathrm{Bbl}$ & Ton & 26.9 & 941 & 8.5 & 4,094 \\
\hline 4 & Light fuel oil & $\mathrm{OIP}$ & $\mathrm{Bbl}$ & Ton & 23.8 & 953 & 8.0 & 5,005 \\
\hline 5 & Heavy fuel oils & OIP & $\mathrm{Bbl}$ & Ton & 16.3 & 433 & 6.7 & 3,991 \\
\hline 6 & Lubricating oils & OIP & $\mathrm{Bbl}$ & Ton & 47.5 & 2,069 & 7.1 & 6,165 \\
\hline 7 & Paving grade asphalts & OIP & $\mathrm{Bbl}$ & Ton & 17.6 & 588 & 6.1 & 5,511 \\
\hline 8 & Natural gas & GAS & $1,000 \mathrm{cu} \mathrm{ft}$ & $1,000 \mathrm{cu} \mathrm{m}$ & 2.36 & 39.90 & 35.3 & 478 \\
\hline 9 & Processed anthracite & $\mathrm{COA}$ & $\mathrm{S}$ ton & Ton & 66.8 & 140.9 & 1.1 & 1,913 \\
\hline 10 & Processed lignite & $\mathrm{COA}$ & S ton & Ton & 26.4 & 78.2 & 1.1 & 2,687 \\
\hline 11 & Peat, CAN & $\mathrm{COA}$ & Ton & Ton & 113.4 & 129.0 & 1 & 1,137 \\
\hline 12 & Crude iron ore & FER* & Ton & Ton & 8.44 & 101.1 & 1 & 11,976 \\
\hline 13 & Non-clay refractory & FER* & Ton & Ton & 1,725 & 2,644 & 1 & 1,533 \\
\hline 14 & Pig iron & FER & S ton & Ton & 269 & 1,246 & 1.1 & 4,195 \\
\hline 15 & Ductile iron castings & FER & S ton & Ton & 1,313 & 5,303 & 1.1 & 3,664 \\
\hline 16 & Steel bars & FER & Ton & Ton & 437 & 2,592 & 1 & 5,934 \\
\hline 17 & Carbon steel, sheet & FER & Ton & Ton & 640 & 2,134 & 1 & 3,336 \\
\hline 18 & Cold rolled sheet & FER & Ton & Ton & 493 & 3,189 & 1 & 6,471 \\
\hline 19 & Steel, pipe, and tubing & FER & Ton & Ton & 715 & 3,618 & 1 & 5,063 \\
\hline 20 & All type steel, strip & FER & Ton & Ton & 678 & 5,129 & 1 & 7,565 \\
\hline 21 & Ferrosilicon & FER & $\mathrm{S}$ ton & Ton & 805 & 2,232 & 1.1 & 2,516 \\
\hline 22 & Coke & FER* & $S$ ton & Ton & 82.89 & 556 & 1.1 & 6,089 \\
\hline 23 & Bauxite & NFR* & Ton & Ton & 24.64 & 200 & 1 & 8,117 \\
\hline 24 & Primary aluminum & NFR & $\mathrm{S}$ ton & Ton & 1,367 & 8,670 & 1.1 & 5,753 \\
\hline 25 & Refined primary cathode copper & NFR & S ton & Ton & 1,487 & 11,754 & 1.1 & 7,171 \\
\hline 26 & Refined zinc & NFR & Ton & Ton & 2,323 & 7,822 & 1 & 3,367 \\
\hline 27 & Primary lead & NFR & Ton & Ton & 1,030 & 4,644 & 1 & 4,511 \\
\hline 28 & Nickel & NFR & $\mathrm{Lb}$ & Ton & 3.14 & 38,819 & 2,205 & 5,608 \\
\hline 29 & Tin & NFR & $\mathrm{Lb}$ & Ton & 3.82 & 36,950 & 2,205 & 4,393 \\
\hline 30 & Coiled aluminum & NFR & S ton & Ton & 2,102 & 18,744 & 1.1 & 8,090 \\
\hline 31 & Gold & NFR & $\mathrm{Kg}$ & $\mathrm{Kg}$ & 10,694 & 61,927 & 1 & 5,791 \\
\hline 32 & Silver & NFR & $\mathrm{Kg}$ & $\mathrm{Kg}$ & 157.21 & 955 & 1 & 6,074 \\
\hline 33 & Raw diamonds, CAN & NFR & Carat & Carat & 145.83 & 470 & 1 & 3,220 \\
\hline 34 & Phosphate rock & $\mathrm{CHE}^{*}$ & Ton & Ton & 23.79 & 201 & 1 & 8,455 \\
\hline 35 & Sulfur & $\mathrm{CHE}$ & Ton & Ton & 35.10 & 78.18 & 1 & 2,228 \\
\hline 36 & $\begin{array}{l}\text { Synthetic ammonia, nitric acid, } \\
\text { and ammonium compounds }\end{array}$ & $\mathrm{CHE}$ & Ton & Ton & 151.29 & 860 & 1 & 5,684 \\
\hline 37 & Phosphoric acid & $\mathrm{CHE}$ & Ton & Ton & 113.47 & 1,113 & $1]$ & 9,812 \\
\hline 38 & $\begin{array}{l}\text { Potassium salts and boron } \\
\text { compounds }\end{array}$ & $\mathrm{CHE}$ & Ton & Ton & 167.82 & 373 & 1 & 2,220 \\
\hline 39 & Sulfuric acid & $\mathrm{CHE}$ & $S$ ton & Ton & 40.76 & 261 & 1.1 & 5,808 \\
\hline 40 & Soda ash & $\mathrm{CHE}$ & Ton & Ton & 85.51 & 694 & 1 & 8,120 \\
\hline 41 & Caustic soda, sodium hydroxide & $\mathrm{CHE}$ & Ton & Ton & 139.91 & 1,713 & 1 & 12,241 \\
\hline 42 & Hydrochloric acid & $\mathrm{CHE}$ & $\mathrm{S}$ ton & Ton & 79.99 & 252 & 1.1 & 2,852 \\
\hline 43 & Carbon black & $\mathrm{CHE}$ & $\mathrm{Lb}$ & Ton & 0.25 & 4,887 & 2,205 & 8,873 \\
\hline 44 & Polyethylene & $\mathrm{CHE}$ & $\mathrm{Lb}$ & Ton & 0.21 & 4,291 & 2,205 & 9,159 \\
\hline 45 & Thermoplastics resins & $\mathrm{CHE}$ & $\mathrm{Lb}$ & Ton & 0.53 & 1,677 & 2,205 & 1,449 \\
\hline 46 & Polyester & $\mathrm{CHE}$ & $\mathrm{Lb}$ & Ton & 0.69 & 13,645 & 2,205 & 9,025 \\
\hline
\end{tabular}




\section{William Davidson Institute Working Paper 428}

\begin{tabular}{|c|c|c|c|c|c|c|c|c|}
\hline & Product name in English & $\begin{array}{l}\text { Sector } \\
\text { code }\end{array}$ & $\begin{array}{l}\text { Unit in the } \\
\text { US }\end{array}$ & $\begin{array}{l}\text { Unit in } \\
\text { Russia }\end{array}$ & $\begin{array}{c}\text { Price of US } \\
\text { unit, \$ } 1\end{array}$ & $\begin{array}{l}\text { Price of Russian } \\
\text { unit, } 1,000 \text { rubles }\end{array}$ & $\begin{array}{c}\text { Conversion } \\
\text { factor }\end{array}$ & $\begin{array}{l}\text { Price ratio, } \\
\text { ruble/\$ }\end{array}$ \\
\hline 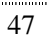 & Rayon & $\mathrm{CHE}$ & $\mathrm{Lb}$ & Ton & 1.15 & 16,303 & 2,205 & 6,430 \\
\hline 48 & Polyester textile yarn & $\mathrm{CHE}$ & $\mathrm{Lb}$ & Ton & 1.32 & 25,768 & 2,205 & 8,869 \\
\hline 49 & Equipment coatings & $\mathrm{CHE}$ & Gallon & Ton & 15.79 & 4,079 & 175 & 1,474 \\
\hline 50 & Architectural coatings & $\mathrm{CHE}$ & Gallon & Ton & 10.99 & 8,992 & 175 & 4,668 \\
\hline 51 & Linseed oil & $\mathrm{CHE}$ & $\mathrm{Lb}$ & Ton & 0.36 & 4,961 & 2,205 & 6,199 \\
\hline 52 & Printing ink & CHE & $\mathrm{Lb}$ & Ton & 1.26 & 237,279 & 2,205 & 85,233 \\
\hline 53 & Styrene-butadiene rubber & $\mathrm{CHE}$ & $\mathrm{Lb}$ & Ton & 0.54 & 11,936 & 2,205 & 10,056 \\
\hline 54 & $\begin{array}{l}\text { Household dry laundry } \\
\text { detergents }\end{array}$ & $\mathrm{CHE}$ & $\mathrm{Lb}$ & Ton & 0.71 & 5,832 & 2,205 & 3,734 \\
\hline 55 & Ethylene & $\mathrm{CHE}$ & $\mathrm{Lb}$ & Ton & 0.26 & 2,108 & 2,205 & 3,749 \\
\hline 56 & Methanol & CHE & Ton & Ton & 187.00 & 1,151 & 1 & 6,155 \\
\hline 57 & Ammonia & CHE & $\mathrm{S}$ ton & Ton & 185.35 & 851 & 1.1 & 4,167 \\
\hline 58 & Acetone & CHE & $\mathrm{Lb}$ & Ton & 0.23 & 3,537 & 2,205 & 6,976 \\
\hline 59 & Light truck pneumatic tires & MAS & Ton & Ton & 53.36 & 904 & 1 & 16,940 \\
\hline 60 & Tractor pneumatic tires & MAS & Ton & Ton & 130.29 & 1,181 & 1 & 9,063 \\
\hline 61 & $\begin{array}{l}\text { Radial passenger car pneumatic } \\
\text { tires }\end{array}$ & MAS & Ton & Ton & 32.65 & 219 & 1 & 6,721 \\
\hline 62 & Protective footwear & MAS & Pair & Pair & 18.94 & 6.85 & 1 & 362 \\
\hline 63 & Rubber products & MAS & Ton & Ton & 14,521 & 71,266 & 1 & 4,908 \\
\hline 64 & $\begin{array}{l}\text { Diesel engine-driven generator } \\
\text { sets }\end{array}$ & MAS & Unit & Unit & 20,655 & 179,546 & 1 & 8,692 \\
\hline 65 & $\begin{array}{l}\text { Underground face haulage } \\
\text { vehicles }\end{array}$ & MAS & Unit & Unit & 642,546 & 280,167 & 1 & 436 \\
\hline 66 & Cranes, lattice boom & MAS & Unit & Unit & 393,000 & 279,308 & 1 & 711 \\
\hline 67 & Wheel cranes & MAS & Unit & Unit & 157,849 & 281,255 & 1 & 1,782 \\
\hline 68 & $\begin{array}{l}\text { Locomotives, both new and } \\
\text { rebuilt }\end{array}$ & MAS & Unit & Unit & $3,457,446$ & $6,576,479$ & 1 & 1,902 \\
\hline 69 & $\begin{array}{l}\text { New freight train and passenger } \\
\text { train cars }\end{array}$ & MAS & Unit & Unit & 57,344 & 349,248 & 1 & 6,090 \\
\hline 70 & Motors and generators & MAS & Unit & Unit & 123 & 1,722 & 1 & 13,958 \\
\hline 71 & Prime mover generator sets & MAS & Unit & Unit & 3,111 & 88,963 & 1 & 28,596 \\
\hline 72 & Welders & MAS & Unit & Unit & 3,018 & 26,013 & 1 & 8,619 \\
\hline 73 & Switches for electrical circuitry & MAS & Unit & Unit & 1.83 & 45.98 & 1 & 25,091 \\
\hline 74 & Plate and filament transformers & MAS & Unit & $\mathrm{kW}$ & 8.03 & 64.42 & 5 & 1,605 \\
\hline 75 & Diodes and rectifiers & MAS & Unit & Unit & 0.24 & 0.32 & 1 & 1,314 \\
\hline 76 & Electric lighting fixtures & MAS & Unit & Unit & 20.36 & 26.37 & 1 & 1,296 \\
\hline 77 & $\begin{array}{l}\text { Electric ranges, ovens, and } \\
\text { surface cookers }\end{array}$ & MAS & Unit & Unit & 252.4 & 1,196 & 1 & 4,737 \\
\hline 78 & Storage batteries & MAS & Unit & Unit & 24.21 & 343 & 1 & 14,182 \\
\hline 79 & Power wire and cable & MAS & $\mathrm{Lb}$ & $\mathrm{Km}$ & 5.83 & 11,309 & 1,424 & 1,363 \\
\hline 80 & Telephone and telegraph wire & MAS & $\mathrm{Lb}$ & $\mathrm{Km}$ & 4.44 & 9,317 & 494 & 4,252 \\
\hline 81 & Bare copper wire & MAS & S ton & Ton & 2,424 & 22,366 & 1.1 & 8,371 \\
\hline 82 & Centrifugal pumps & MAS & Unit & Unit & 303 & 7,725 & 1 & 25,489 \\
\hline 83 & Oil well pumps & MAS & Unit & Unit & 5,554 & 32,898 & 1 & 5,923 \\
\hline 84 & Air compressors & MAS & Unit & Unit & 948 & 19,286 & 1 & 20,346 \\
\hline 85 & Trucks & MAS & Unit & Unit & 33,826 & 64,174 & 1 & 1,897 \\
\hline 86 & Passenger cars & MAS & Unit & Unit & 15,831 & 30,831 & 1 & 1,948 \\
\hline 87 & Buses & MAS & Unit & Unit & 47,547 & 58,517 & 1 & 1,231 \\
\hline 88 & Trailers and semi-trailers & MAS & Unit & Unit & 2,872 & 40,291 & 1 & 14,027 \\
\hline 89 & Ball bearings, complete & MAS & Unit & Unit & 3.42 & 13.54 & 1 & 3,955 \\
\hline 90 & Wagons & MAS & Unit & Unit & 1,823 & 12,349 & 1 & 6,773 \\
\hline 91 & Farm-type tractors & MAS & Unit & Unit & 22,912 & 168,945 & 1 & 7,374 \\
\hline
\end{tabular}




\section{William Davidson Institute Working Paper 428}

\begin{tabular}{|c|c|c|c|c|c|c|c|c|}
\hline & Product name in English & $\begin{array}{l}\text { Sector } \\
\text { code }\end{array}$ & $\begin{array}{l}\text { Unit in the } \\
\text { US }\end{array}$ & $\begin{array}{l}\text { Unit in } \\
\text { Russia }\end{array}$ & $\begin{array}{c}\text { Price of US } \\
\text { unit, } \$ 1\end{array}$ & $\begin{array}{c}\text { Price of Russian } \\
\text { unit, } 1,000 \text { rubles }\end{array}$ & $\begin{array}{c}\text { Conversion } \\
\text { factor }\end{array}$ & $\begin{array}{l}\text { Price ratio, } \\
\text { ruble/\$ }\end{array}$ \\
\hline 92 & Plows and sub-soilers & MAS & Unit & Unit & 7,563 & 4,076 & 1 & 539 \\
\hline 93 & Grain drills & MAS & Unit & Unit & 17,595 & 20,130 & 1 & 1,144 \\
\hline 94 & Combines & MAS & Unit & Unit & 21,809 & 212,914 & 1 & 9,763 \\
\hline 95 & $\begin{array}{l}\text { Front and rear tractor mounted } \\
\text { loaders }\end{array}$ & MAS & Unit & Unit & 2,970 & 15,567 & 1 & 5,241 \\
\hline 96 & Excavators & MAS & Unit & Unit & 103,439 & 225,264 & 1 & 2,178 \\
\hline 97 & Crawler tractors & MAS & Unit & Unit & 147,917 & 270,833 & 1 & 1,831 \\
\hline 98 & General white lamps & MAS & Unit & 1,000 units & 0.32 & 988 & 1,000 & 3,058 \\
\hline 99 & Bicycles & MAS & Unit & Unit & 129 & 455 & 1 & 3,532 \\
\hline 100 & Gas household ranges & MAS & Unit & Unit & 331 & 492 & 1 & 1,487 \\
\hline 101 & Waffle irons & MAS & Unit & Unit & 24.1 & 46 & 1 & 1,900 \\
\hline 102 & Household refrigerators & MAS & Unit & Unit & 438 & 1,457 & 1 & 3,326 \\
\hline 103 & Household laundry machines & MAS & Unit & Unit & 263 & 502 & 1 & 1,910 \\
\hline 104 & Household television receivers & MAS & Unit & Unit & 372 & 614 & 1 & 1,652 \\
\hline 105 & Softwood logs and bolts & FOR & $\mathrm{Cu} \mathrm{m}$ & $\mathrm{Cu} \mathrm{m}$ & 21.6 & 137 & 1 & 6,342 \\
\hline 106 & Softwood lumber, edge worked & FOR & $1,000 \mathrm{bd} \mathrm{ft}$ & $\mathrm{Cu} \mathrm{m}$ & 0.55 & 389 & 588 & 1,200 \\
\hline 107 & Softwood, not edge worked & FOR & $1,000 \mathrm{bd} \mathrm{ft}$ & $\mathrm{Cu} \mathrm{m}$ & 0.39 & 294 & 588 & 1,270 \\
\hline 108 & Panel Douglas fir doors & FOR & Unit & $\mathrm{Sq} \mathrm{m}$ & 119 & 150 & 0.38 & 3,331 \\
\hline 109 & Double hung wood windows & FOR & Unit & $\mathrm{Sq} \mathrm{m}$ & 168 & 269 & 0.56 & 2,858 \\
\hline 110 & Interior softwood plywood & FOR & $\mathrm{Sq} \mathrm{ft}, 3 / 8$ & $\mathrm{Cu} \mathrm{m}$ & 0.23 & 2,040 & 1,689 & 7,934 \\
\hline 111 & Particleboard & FOR & $\mathrm{Sq} \mathrm{ft}, 3 / 4$ & $\mathrm{Cu} \mathrm{m}$ & 0.28 & 743 & 1,392 & 4,703 \\
\hline 112 & Wafer- and oriented strandboard & FOR & $\mathrm{Sq} \mathrm{ft}, 3 / 4$ & $\mathrm{Sq} \mathrm{m}$ & 0.12 & 4.24 & 10.8 & 3,407 \\
\hline 113 & Wood tables & FOR & Unit & Unit & 189 & 338 & 1 & 1,789 \\
\hline 114 & Wood chairs & FOR & Unit & Unit & 68 & 118 & 1 & 1,721 \\
\hline 115 & Upholstered wood sofas & FOR & Unit & Unit & 335 & 1,207 & 1 & 3,602 \\
\hline 116 & Clay-coated paper & FOR & $\mathrm{S}$ ton & Ton & 769 & 2,935 & 1.1 & 3,461 \\
\hline 117 & Unbleached linerboard & FOR & $S$ ton & Ton & 334 & 2,987 & 1.1 & 8,122 \\
\hline 118 & Sulfate wood pulp & FOR* & $S$ ton & Ton & 439 & 3,279 & 1.1 & 6,779 \\
\hline 119 & Portland cement & $\mathrm{CSM}$ & $\mathrm{S}$ ton & Ton & 66 & 237 & 1.1 & 3,234 \\
\hline 120 & Roofing paper & $\mathrm{CSM}$ & $\mathrm{Sq} \mathrm{ft}$ & $1,000 \mathrm{sq} \mathrm{m}$ & 0.02 & 3,086 & 10,764 & 11,872 \\
\hline 121 & Structural concrete & $\mathrm{CSM}$ & Cu yard & $\mathrm{Cu} \mathrm{m}$ & 303 & 868 & 1.31 & 2,191 \\
\hline 122 & Prestressed concrete panels & $\mathrm{CSM}$ & $\mathrm{Sq} \mathrm{ft}$ & $\mathrm{Cu} \mathrm{m}$ & 4.77 & 868 & 90 & 2,029 \\
\hline 123 & Gypsum plaster building boards & $\mathrm{CSM}$ & $\mathrm{S}$ ton & 1,000 stand. & 128 & 520 & 4.19 & 974 \\
\hline 124 & Concrete sewer pipe & $\mathrm{CSM}$ & $\mathrm{S}$ ton & Standard m & 109 & 17.59 & 0.01 & 17,195 \\
\hline 125 & Brick & CSM & Unit & 1,000 bricks & 0.17 & 611 & 1,913 & 1,837 \\
\hline 126 & Clay tile & $\mathrm{CSM}$ & $\mathrm{Sq} \mathrm{ft}$ & $\mathrm{Sq} \mathrm{m}$ & 1.37 & 39.68 & 11 & 2,682 \\
\hline 127 & Quicklime & CSM & $\mathrm{S}$ ton & Ton & 54.1 & 229 & 1.1 & 3,833 \\
\hline 128 & Mined gypsum & $\mathrm{CSM}$ & Ton & Ton & 7.10 & 351 & 1 & 49,424 \\
\hline 129 & Construction gravel & CSM & $\mathrm{S}$ ton & Ton & 5.21 & 41.59 & 1.1 & 7,235 \\
\hline 130 & Construction sand & $\mathrm{CSM}$ & $\mathrm{S}$ ton & Ton & 4.34 & 30.35 & 1.1 & 6,343 \\
\hline 131 & Asbestos & $\mathrm{CSM}$ & Ton & Ton & 222 & 934 & 1 & 4,205 \\
\hline 132 & Linoleum & $\mathrm{CSM}$ & Sq yard & $\mathrm{Sq} \mathrm{m}$ & 9.50 & 23.89 & 1.2 & 2,103 \\
\hline 133 & Flat glass, construction & CSM & $\mathrm{Sq} \mathrm{ft}$ & $\mathrm{Sq} \mathrm{m}$ & 0.30 & 15.15 & 10.8 & 4,699 \\
\hline 134 & Flat glass, window & CSM & $\mathrm{Sq} \mathrm{ft}$ & $\mathrm{Sq} \mathrm{m}$ & 0.30 & 12.75 & 10.8 & 3,955 \\
\hline 135 & Tableware & $\mathrm{CSM}$ & Unit & Unit & 1.26 & 5.22 & 1 & 4,133 \\
\hline 136 & Carded cotton yarns & TEX* & $\mathrm{Lb}$ & Ton & 1.37 & 16,495 & 2,205 & 5,454 \\
\hline 137 & Cotton broad woven fabrics & TEX & Sq yd & Fabric m & 1.38 & 3.96 & 1.2 & 2,398 \\
\hline 138 & Wool yarns & TEX* & $\mathrm{Lb}$ & Ton & 4.11 & 28,347 & 2,205 & 3,125 \\
\hline 139 & Wool broad woven fabrics & TEX & Sq yd & Fabric m & 3.03 & 37.50 & 1.2 & 10,340 \\
\hline
\end{tabular}




\section{William Davidson Institute Working Paper 428}

\begin{tabular}{|c|c|c|c|c|c|c|c|c|}
\hline & Product name in English & $\begin{array}{l}\text { Sector } \\
\text { code }\end{array}$ & $\begin{array}{l}\text { Unit in the } \\
\text { US }\end{array}$ & $\begin{array}{l}\text { Unit in } \\
\text { Russia }\end{array}$ & $\begin{array}{c}\text { Price of US } \\
\text { unit, \$ } 1\end{array}$ & $\begin{array}{l}\text { Price of Russian } \\
\text { unit, } 1,000 \text { rubles }\end{array}$ & $\begin{array}{c}\text { Conversion } \\
\text { factor }\end{array}$ & $\begin{array}{l}\text { Price ratio, } \\
\text { ruble/\$ }\end{array}$ \\
\hline 140 & Manmade silk fabrics & TEX & Sq yd & Sq m & 4.47 & 9.64 & 1.2 & 1,803 \\
\hline 141 & Sheer hosiery & TEX & Doz pairs & Pair & 2.79 & 4.91 & 0.08 & 21,133 \\
\hline 142 & Women's hosiery & TEX & Doz pairs & Pair & 6.74 & 4.53 & 0.08 & 8,076 \\
\hline 143 & Men's hosiery & TEX & Doz pairs & Pair & 7.87 & 2.99 & 0.08 & 4,562 \\
\hline 144 & Children's finished anklets & TEX & Doz pairs & Pair & 5.66 & 6.36 & 0.08 & 13,489 \\
\hline 145 & Men's underwear & TEX & Unit & Unit & 1.24 & 7.24 & 1 & 5,863 \\
\hline 146 & Men's and women's sweaters & TEX & Unit & Unit & 12.95 & 42.3 & 1 & 3,264 \\
\hline 147 & Men's overcoats & TEX & Unit & Unit & 69.2 & 242 & 1 & 3,494 \\
\hline 148 & $\begin{array}{l}\text { Women's \& girls' apparel } \\
\text { dresses }\end{array}$ & TEX & Unit & Unit & 24.4 & 56.1 & 1 & 2,295 \\
\hline 149 & $\begin{array}{l}\text { Men's \& boys' woven dress } \\
\text { shirts }\end{array}$ & TEX & Unit & Unit & 11.7 & 27.9 & 1 & 2,384 \\
\hline 150 & Men's dress coats & TEX & Unit & Unit & 62.4 & 187 & 1 & 2,987 \\
\hline 151 & Sheet sets & TEX & Dozen & Unit & 216 & 29.8 & 0.08 & 1,654 \\
\hline 152 & Upholstery leather & TEX & $\mathrm{Sq} \mathrm{ft}$ & $\mathrm{Sqdm}$ & 2,944 & 1,162 & 0.11 & 3,665 \\
\hline 153 & Wet blues leathers & TEX & $\mathrm{Sq} \mathrm{ft}$ & $\mathrm{Sq} d \mathrm{~m}$ & 8,529 & 732 & 0.11 & 797 \\
\hline 154 & Upper leather & TEX & $\mathrm{Sq} \mathrm{ft}$ & $\mathrm{Sq} \mathrm{dm}$ & 2,374 & 726 & 0.11 & 2,840 \\
\hline 155 & Women's handbags & TEX & Unit & Unit & 21.9 & 51 & 1 & 2,308 \\
\hline 156 & Men's footwear & TEX & Pair & Pair & 48.5 & 125 & 1 & 2,575 \\
\hline 157 & Beet sugar & $\mathrm{FOO}$ & $\mathrm{S}$ ton & Ton & 576 & 2,671 & 1.1 & 4,210 \\
\hline 158 & Rye bread & $\mathrm{FOO}$ & $\mathrm{Lb}$ & Ton & 0.80 & 2,197 & 2,205 & 1,247 \\
\hline 159 & White pan bread & $\mathrm{FOO}$ & $\mathrm{Lb}$ & Ton & 0.62 & 3,744 & 2,205 & 2,737 \\
\hline 160 & Sweetened chocolate & $\mathrm{FOO}$ & $\mathrm{Lb}$ & Ton & 1.10 & 16,451 & 2,205 & 6,756 \\
\hline 161 & Cookies and wafers & $\mathrm{FOO}$ & $\mathrm{Lb}$ & Ton & 1.43 & 7,418 & 2,205 & 2,355 \\
\hline 162 & Crude soybean oil & $\mathrm{FOO}$ & $\mathrm{Lb}$ & Ton & 0.23 & 3,735 & 2,205 & 7,378 \\
\hline 163 & Spoon-type mayonnaise & $\mathrm{FOO}$ & Gallon & Ton & 4.02 & 8,671 & 240 & 8,968 \\
\hline 164 & Dry macaroni & $\mathrm{FOO}$ & $\mathrm{Lb}$ & Ton & 0.59 & 4,188 & 2,205 & 3,231 \\
\hline 165 & Complete chicken feed** & $\mathrm{FOO}$ & $\mathrm{S}$ ton & Ton & 188 & 958 & 1.10 & 4,613 \\
\hline 166 & Bottled unprocessed whiskey & $\mathrm{FOO}$ & Wine gal & 10 liters & 14.15 & 43.38 & 2.64 & 1,161 \\
\hline 167 & Bottled vodka & $\mathrm{FOO}$ & Wine gal & 10 liters & 11.39 & 54.08 & 2.64 & 1,797 \\
\hline 168 & White grape wines & FOO & Wine gal & 10 liters & 6.30 & 69.38 & 2.64 & 4,169 \\
\hline 169 & Canned beer & $\mathrm{FOO}$ & Case & 10 liters & 27.54 & 29.08 & 2.35 & 450 \\
\hline 170 & Bottled carbonated soft drinks & $\mathrm{FOO}$ & Case & 10 liters & 3.36 & 20.77 & 1.76 & 3,505 \\
\hline 171 & Compressed yeast & FOO & $\mathrm{Lb}$ & Ton & 0.32 & 4,577 & 2,205 & 6,405 \\
\hline 172 & $\begin{array}{l}\text { Canned beans, corn, and } \\
\text { tomatoes }\end{array}$ & FOO & Case & Ton & 8.10 & 2,701 & 35.2 & 9,468 \\
\hline 173 & Canned milk & $\mathrm{FOO}$ & $\mathrm{Lb}$ & Standard can & 0.64 & 2.24 & 0.88 & 3,968 \\
\hline 174 & Tea & FOO & $\mathrm{Lb}$ & Ton & 4.91 & 18,444 & 2,205 & 1,705 \\
\hline 175 & Table salt, evaporated & $\mathrm{FOO}$ & $\mathrm{S}$ ton & Ton & 384 & 504 & 1.1 & 1,189 \\
\hline 176 & Filter tip cigarettes & FOO & $1,000 \mathrm{~s}$ & $1,000 \mathrm{~s}$ & 40.2 & 26.06 & 1 & 649 \\
\hline 177 & Beef & $\mathrm{FOO}$ & $\mathrm{Lb}$ & Ton & 1.06 & 10,903 & 2,205 & 4,662 \\
\hline 178 & Smoked sliced bacon & $\mathrm{FOO}$ & $\mathrm{Lb}$ & Ton & 1.45 & 13,828 & 2,205 & 4,312 \\
\hline 179 & Wet ice pack broilers & $\mathrm{FOO}$ & $\mathrm{Lb}$ & Ton & 0.56 & 11,474 & 2,205 & 9,354 \\
\hline 180 & Other sausage & $\mathrm{FOO}$ & $\mathrm{Lb}$ & Ton & 1.65 & 18,087 & 2,205 & 4,963 \\
\hline 181 & Regular yogurt & $\mathrm{FOO}$ & $\mathrm{Lb}$ & Ton & 0.79 & 3,366 & 2,205 & 1,936 \\
\hline 182 & Sour cream & $\mathrm{FOO}$ & $\mathrm{Qt}$ & Ton & 0.85 & 9,579 & 1,057 & 10,612 \\
\hline 183 & Natural cheese & $\mathrm{FOO}$ & $\mathrm{Lb}$ & Ton & 1.40 & 18,627 & 2,205 & 6,031 \\
\hline 184 & Process cheese & $\mathrm{FOO}$ & $\mathrm{Lb}$ & Ton & 1.84 & 13,677 & 2,205 & 3,365 \\
\hline 185 & Creamery butter & $\mathrm{FOO}$ & $\mathrm{Lb}$ & Ton & 1.13 & 20,390 & 2,205 & 8,198 \\
\hline 186 & Fluid whole milk & $\mathrm{FOO}$ & $\mathrm{Lb}$ & Ton & 0.15 & 2,265 & 2,205 & 7,053 \\
\hline
\end{tabular}




\section{William Davidson Institute Working Paper 428}

\begin{tabular}{|c|c|c|c|c|c|c|c|c|}
\hline & Product name in English & $\begin{array}{l}\text { Sector } \\
\text { code }\end{array}$ & $\begin{array}{l}\text { Unit in the } \\
\text { US }\end{array}$ & $\begin{array}{l}\text { Unit in } \\
\text { Russia }\end{array}$ & $\begin{array}{c}\text { Price of US } \\
\text { unit, } \$ 1\end{array}$ & $\begin{array}{l}\text { Price of Russian } \\
\text { unit, } 1000 \text { rubles }\end{array}$ & $\begin{array}{c}\text { Conversion } \\
\text { factor }\end{array}$ & $\begin{array}{l}\text { Price ratio, } \\
\text { ruble } / \$\end{array}$ \\
\hline 187 & Prepared fresh fish & FOO & $\mathrm{Lb}$ & Ton & 1.81 & 5,667 & 2,205 & 1,418 \\
\hline 188 & Prepared frozen fish & $\mathrm{FOO}$ & $\mathrm{Lb}$ & Ton & 1.30 & 3,792 & 2,205 & 1,327 \\
\hline 189 & Finfish, CAN & FOO & Ton & Ton & 4,056 & 9,995 & 1 & 2,464 \\
\hline 190 & Salted and pickled fish & $\mathrm{FOO}$ & $\mathrm{Lb}$ & Ton & 1.41 & 8,422 & 2,205 & 2,707 \\
\hline 191 & Canned salmon & $\mathrm{FOO}$ & $\mathrm{Lb}$ & Standard can & 1.30 & 4,252 & 882 & 3,702 \\
\hline 192 & White bread flour & $\mathrm{FOO}$ & Sack & Ton & 11.46 & 1,965 & 22 & 7,774 \\
\hline 193 & Whole cornmeal & $\mathrm{FOO}$ & Sack & Ton & 11.97 & 1,751 & 22 & 6,635 \\
\hline 194 & Bulgur flour & FOO & Sack & Ton & 21.26 & 3,012 & 22 & 6,426 \\
\hline 195 & Semolina & FOO & Sack & Ton & 14.20 & 2,574 & 22 & 8,222 \\
\hline 196 & Head rice & FOO & $\mathrm{Lb}$ & Ton & 0.11 & 2,826 & 2,205 & 12,191 \\
\hline 197 & Newspaper & OTH & Unit & Unit & 1.33 & 0.76 & 1 & 575 \\
\hline 198 & Book & $\mathrm{OTH}$ & Unit & Unit & 15.65 & 16.04 & 1 & 1,025 \\
\hline 199 & Aspirin & OTH & Pack, $5 \mathrm{~g}$ & Pack, $5 \mathrm{~g}$ & 1.49 & 0.99 & 1 & 668 \\
\hline 200 & Nitroglycerin & OTH & Pack, $15 \mathrm{mg}$ & Pack, $5 \mathrm{mg}$ & 29.94 & 0.35 & 0.33 & 35 \\
\hline 201 & Erythromycin & OTH & Pack, $25 \mathrm{~g}$ & Pack, $2.5 \mathrm{~g}$ & 18.53 & 7.80 & 0.10 & 4,210 \\
\hline 202 & Vitamin C & OTH & Pack, $120 \mathrm{~g}$ & $\mathrm{Kg}$ & 14.61 & 114 & 8.33 & 940 \\
\hline 203 & Wheat & AGR & $\mathrm{Bu}$ & Ton & 3.38 & 599 & 37 & 4,825 \\
\hline 204 & Rye & AGR & $\mathrm{Bu}$ & Ton & 3.75 & 580 & 39 & 3,927 \\
\hline 205 & Buckwheat, CAN & AGR & $\mathrm{Bu}$ & Ton & 4.69 & 978 & 39 & 5,296 \\
\hline 206 & Corn for grain & AGR & $\mathrm{Bu}$ & Ton & 2.43 & 784 & 39 & 8,194 \\
\hline 207 & Barley & AGR & $\mathrm{Bu}$ & Ton & 2.38 & 476 & 46 & 4,357 \\
\hline 208 & Soybeans & AGR & Cwt & Ton & 12.10 & 879 & 22 & 3,293 \\
\hline 209 & Oat & AGR & $\mathrm{Bu}$ & Ton & 1.60 & 492 & 69 & 4,465 \\
\hline 210 & Sunflowers seeds & AGR & $\mathrm{Cwt}$ & Ton & 11.60 & 749 & 22 & 2,927 \\
\hline 211 & Sugar beets & AGR & Ton & Ton & 38.80 & 183 & 1 & 4,719 \\
\hline 212 & Potatoes & AGR & $\mathrm{Cwt}$ & Ton & 6.11 & 940 & 22 & 6,984 \\
\hline 213 & Tomatoes & AGR & $\mathrm{Cwt}$ & Ton & 31.74 & 3,605 & 22 & 5,152 \\
\hline 214 & Cucumbers & AGR & $\mathrm{Cwt}$ & Ton & 17.69 & 4,808 & 22 & 12,331 \\
\hline 215 & Onions & AGR & $\mathrm{Cwt}$ & Ton & 11.20 & 886 & 22 & 3,591 \\
\hline 216 & Garlic & AGR & $\mathrm{Cwt}$ & Ton & 47.91 & 5,429 & 22 & 5,140 \\
\hline 217 & Cabbages & AGR & $\mathrm{Cwt}$ & Ton & 10.81 & 977 & 22 & 4,099 \\
\hline 218 & Carrots & AGR & Cwt & Ton & 12.88 & 1,093 & 22 & 3,846 \\
\hline 219 & Beets & AGR & Ton & Ton & 66.65 & 987 & 1 & 14,802 \\
\hline 220 & Cherries and peaches & AGR & $\mathrm{Lb}$ & Ton & 0.24 & 1,255 & 2,205 & 2,364 \\
\hline 221 & Apples and pears & AGR & $\mathrm{Lb}$ & Ton & 0.15 & 685 & 2,205 & 2,091 \\
\hline 222 & Strawberries & AGR & Cwt & Ton & 55.50 & 4,259 & 22 & 3,481 \\
\hline 223 & Grapes & AGR & $\mathrm{Lb}$ & Ton & 0.19 & 1,192 & 2,205 & 2,789 \\
\hline 224 & Honeydews \& watermelons & AGR & $\mathrm{Cwt}$ & Ton & 8.85 & 300 & 22 & 1,536 \\
\hline 225 & Cattle and calves & AGR & $\mathrm{Lb}$ & Ton & 0.61 & 3,448 & 2,205 & 2,578 \\
\hline 226 & Sheep and lambs & AGR & $\mathrm{Lb}$ & Ton & 0.81 & 2,410 & 2,205 & 1,345 \\
\hline 227 & Hogs and pigs & AGR & $\mathrm{Lb}$ & Ton & 0.52 & 6,149 & 2,205 & 5,329 \\
\hline 228 & Broilers & AGR & $\mathrm{Lb}$ & Ton & 0.38 & 6,055 & 2,205 & 7,282 \\
\hline 229 & Milk & AGR & $\mathrm{Lb}$ & Ton & 0.14 & 975 & 2,205 & 3,267 \\
\hline 230 & Eggs & AGR & Unit & $1,000 \mathrm{~s}$ & 0.06 & 372 & 1,000 & 6,348 \\
\hline 231 & Wool & AGR & $\mathrm{Lb}$ & Ton & 0.84 & 3,943 & 2,205 & 2,134 \\
\hline 232 & All hay, baled & AGR* & Ton & Ton & 100 & 92 & 1 & 919 \\
\hline
\end{tabular}

Sources: Prices per US unit are from US Bureau of Census, US Department of Agriculture, US Department of Interior (recalculated as the ratio of total value to output in physical units), different publications and several commercial sources; prices per Russian unit are from GKS [1998d, Table 4.11, 2.20, 6.2] and commercial sources; conversion factors are from US Department of Energy, US Bureau of Census and Russian and American 


\section{William Davidson Institute Working Paper 428}

commercial sources; Price ratios are the ratios of Russian prices to the product of US prices times conversion factor. CAN means that Canadian values are used converted in US dollars, * implies that the product is used by the sector internally, ** defines the only product (chicken feed) that is consumed by a specific sector

Some products are consumed by one sector and they are counted for that sector only. This is not vital for our research but it should improve the accuracy of our results. We consider iron ore, coke, bauxite, pulp, yarns, animal feed, and hay to be products intended for internal consumption. They are not included in the sample of products that are used by more than one sector. As it is seen in Table B3, the price ratios for products consumed within sectors and in general do not differ much.

Table B3: Sectoral price ratios, in rubles per dollar.

\begin{tabular}{|c|c|c|c|c|}
\hline & Sector & Code & $\begin{array}{l}\text { Price ratio: General } \\
\text { consumption }\end{array}$ & $\begin{array}{l}\text { Price ratio: Internal } \\
\text { consumption }\end{array}$ \\
\hline 1 & Electricity & ELE & $\begin{array}{r}3,237 \\
-r .\end{array}$ & The same \\
\hline 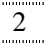 & Oil extraction & 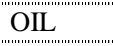 & 2,765 & The same \\
\hline 3 & Oil processing & 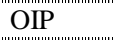 & 4,488 & The same \\
\hline "3t"m & Gas extraction & GAS & 478 & The same \\
\hline 5 & Coal and other fuels mining & COA & 2,005 & The same \\
\hline 6 & Iron and steel & 'FER & 4,103 & 4,114 \\
\hline 7 & Non-ferrous metallurgy & NFR & 3,942 & 3,973 \\
\hline "l'm & Chemical and petrochemical industry & "'llwE & 5,368 & 5,393 \\
\hline 9 & Machine building and metal processing & MAS & 2,210 & The same \\
\hline 10 & Wood and paper & FOR & 2,875 & 3,349 \\
\hline 111 & Construction materials & CSM & 2,583 & The same \\
\hline 12 & Textile, apparel, and footwear & TEX & 2,898 & 3,134 \\
\hline 13 & Food processing & $\mathrm{FOO}$ & 2,499 & The same \\
\hline "14" & Other industries & OTH & 794 & The same \\
\hline \multirow[t]{2}{*}{15} & Agriculture and forestry & AGR & 4,418 & 4,257 \\
\hline & Memo: PPP price ratio & & 2,384 & \\
\hline
\end{tabular}

Sources: Author's calculations

The generic formula for finding the matrix of intermediate costs Table $\mathbf{P P P}$ converted at the sectoral Price ratios is

Table $_{\text {PPP }}=$ Rate $^{-1} \circ$ Table $_{\text {I } / 097}$

where Rate is a diagonal matrix of the rates. In actual calculations, we divide the entries of the input-output matrix by the relevant rates element by element because for several diagonal entries internal Price ratios should be used.

\footnotetext{
${ }^{54}$ It is interesting to note that items that are produced and consumed within sectors tend to be over-priced relative to its other products. The sample is too small to make any inference what forces might be at play

${ }^{55} \mathrm{It}$ is found as the ratio of GDP in rubles to the estimate of GDP at PPP exchange rates made by the World Bank.
} 


\section{Appendix C: The Methodology of Finding the Value of Import Barriers}

To determine import barriers, we compare American producer's prices of our sample ${ }^{66}$ with Russian prices. If the US price is higher, tariff does not serve as a trade barrier because import is unprofitable. If a Russian price is higher, two situations are possible: tariff markup is lower or higher than the difference in prices. If the tariff is higher, Russian producers do not charge the whole tariff markup. Then, tariff protection accounts for the difference in prices. If the tariff is lower, there is assumed to be an internal factor responsible for non-tariff markup. In this case, tariff rate determines the level of protection. Technically, the formula for finding the rate of price protection for good $j$ is

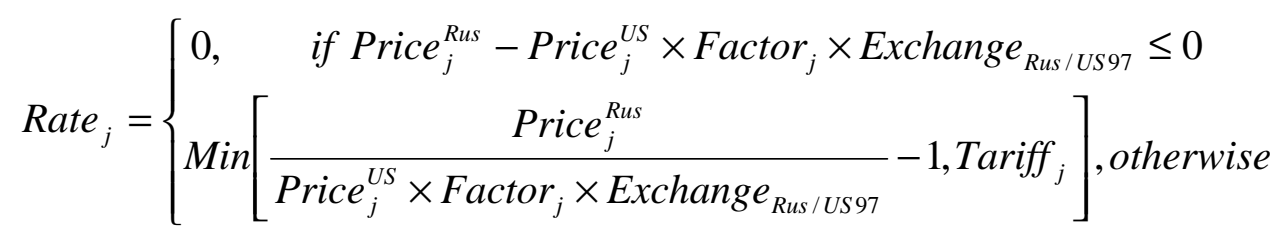

We take import tariff rates as they are reported in the Governmental Decree N 1560 "On the Classification of Products Designated for Foreign-Trade and Custom Tariffs of the Russian Federation" dated December 27, 1996. 17 Correspondence of goods to tariffs is checked using "The Classification of Goods for External Trade of the CIS" by State Custom Committee of the RF, edition of September 19, 1996. ${ }^{-}$Some tariffs are accessed in ECU per unit of a product. To convert unit in ad valorem rates, we multiply the levy by average daily exchange rate for ECU for 1997 set by the CBR and divide by the Russian price of the good in question as

$$
\text { Rate }_{j}=\frac{\text { RateECU }_{j} \times \text { ExchangeRate }^{97}}{\text { Price }_{j}^{\text {Rus }}}
$$

After protection rates are found for each product, we find sectoral protection barriers. At first, the values of import barriers are found as the product of protection rates and non-exported domestic output

$$
\text { Value }_{j}=\frac{\text { Rate }_{j} \times \text { Price }_{j}^{\text {Rus }} \times\left(\text { Output }_{j}-\text { Export }_{j}\right)}{1+\text { Rate }_{j}}
$$

The export share is excluded from the consideration since it is assumed that external trade is conducted at market prices. This assumption might be violated in transactions with the former Soviet states, for prices of products shipped to and received from the CIS countries are generally lower than the average. Nevertheless, we do not expect export prices to change when import tariffs are annulled and exclude exports from the estimated value of tariff protection.

We get data on export values from GKS [1998c, Table 3.9]. When data on the export of a particular good is missing or aggregated, we use the average export share for the sector available from the input-output table instead.

\footnotetext{
${ }^{56}$ US prices are converted in rubles at the average daily CBR exchange rate, which was 5,785 ruble/US \$.

${ }^{57}$ The decree is available at http://www.ist.ru/VP/LIB053/z10500.htm\#P_47. There were no changes of rates during 1997 relevant to our sample apart from rising tariff rate on tea from 10 to 20 percent from June 1.

${ }^{58}$ See Ministry of Economic Development and Trade of the RF at http://www.inves.ru/info/online/tnved/.

${ }^{59}$ In our sample such levy applies to sweetened chocolate only.
} 
The term in denominator appears because tariff rate applies to the foreign price of imported goods. Thus, if the Russian price differs from its foreign analogue by the tariff margin only, it should be equal to

$$
\text { Price }_{j}^{\text {Rus }}=\left(1+\text { Rate }_{j}\right) \times \text { Price }_{j}^{U S}
$$

which is introduced into formula [C3]. Finally, the sectoral protection rates are found as the ratio of the total values of import barrier and the value of output of the sampled goods.

Table $\mathrm{C} 1$ : Weighted average tariff and sectoral protection rates

\begin{tabular}{|c|c|c|c|c|}
\hline & Sector & Code & Average effective rate, in $\%$ & $\begin{array}{l}\text { Tariff and price protection } \\
\text { rate, in \% }\end{array}$ \\
\hline 1 & Electricity & ELE & 5.000 & 0.000 \\
\hline 2 & Oil extraction & OIL & 5.000 & 0.000 \\
\hline 3 & Oil processing & OIP & 5.000 & 0.206 \\
\hline 4 & Gas extraction & GAS & 5.000 & -41.140 \\
\hline 5 & Coal and other fuels mining & COA & 5.000 & 0.000 \\
\hline 6 & Iron and steel & FER & 5.268 & 0.324 \\
\hline (3) 7 & Non-ferrous metallurgy & NFR & 17.872 & 0.135 \\
\hline 8 & Chemical and petrochemical industry & $\mathrm{CHE}$ & 9.302 & 3.636 \\
\hline 9 & Machine building and metal processing & MAS & 23.402 & 0.781 \\
\hline 10 & Wood and paper & FOR & 17.601 & 2.993 \\
\hline 11 & Construction materials & CSM & 9.863 & 0.975 \\
\hline 12 & Textile, apparel, and footwear & TEX & 19.463 & 2.605 \\
\hline 13 & Food processing & FOO & (1) & 3.675 \\
\hline 14 & Other industries & OTH & 2.291 & 0.000 \\
\hline 15 & Agriculture and forestry & AGR & 12.477 & 4.322 \\
\hline
\end{tabular}

Sources: Tariff rates are aggregated by the author using individual rates from the Governmental Decree N 1560 "On the Classification of Products Designated for Foreign-Trade and Custom Tariffs of the Russian Federation" dated December 27, 1996 and weights calculated from the sample presented in Table A2; tariff and price protection rates are author's calculations

Table $\mathrm{C} 1$ presents the sectoral protection rates. Note that the rate for natural gas extraction is negative because the average export price of gas (unregulated) exceeds its domestic price (regulated). ${ }^{60}$ The situation is reversed for electricity where its domestic price (regulated) is higher than the average export price. This observation implies that the domestic price of gas is lower than it would be with no price regulation and perfect competition whereas the price response of electricity sector in similar conditions is uncertain.

\footnotetext{
${ }^{60}$ We take the average price of natural gas that manufacturing establishments pay and not producer's price for this exercise. The reason is that it is the former price that is fixed by the government. It includes transport and trade margin. The average price for manufacturing establishments is from GKS [1998e, Table 24.23]. However, considering the value of output if prices are unregulated, we add trade and transport margins to the sector of gas extraction and subtract this amount from the output of transport and trade sectors. The difference is divided between the last sectors in the proportion to their total margins for the whole economy.
} 


\section{Appendix D: The Methodology of Finding the Index of Processing}

We start with finding the shares of processing for mixed sectors. Russian industrial classification OKONKh details what establishments are considered to be primary (extraction and mining). We take the classification as the base and draw a list of primary products. They are:

- Electricity

- Oil and gas extraction and coal mining

- Ore and non-ore mining for ferrous and non-ferrous metallurgy including diamonds mining

- Chemical mining (apatite, nepheline, phosphates, potassium, natural sulfur, boron, arsenic, barite, and iodine)

- Unprocessed lumber for the sector of wood and paper

- $\quad$ Stones, sand, and clay used for construction purposes (ceramic clay, gravel and construction sand, marble, granite and other decorative stones, limestone, asbestos, kaolin, talcum, pegmatite, mica, and quartz sand

- Table salt and prepared and fresh fish for food processing sector

- Precious and semi-precious stones for the sector of other manufacturing

We define the share of primary production as the value of sectoral primary output to its total value. The values of unprocessed lumber, table salt, and fish are found as the product of average producer price and total output that we have collected in the sample. Data on total output for these sectors is from GKS [1998e, Tables 14.67 and 14.76].

Data on the shares of primary production for other sectors is unavailable in statistical publications. We use the sample of 3,211 companies to find approximate shares py separating the sample into primary and processing establishments and aggregating its output. ${ }_{2}$ The shares are reported in Table D1.

\footnotetext{
${ }^{61}$ OKONKh divides the sector of electricity in primary (hydroelectric power stations) and processing (coal, gas, and nuclear power stations). We consider the whole sector to belong to primary industry.

${ }^{62}$ This is a reduced form of the sample that we introduce in Appendix A, Section A2. It is representative with the smallest number of firms being in the sector of non-ferrous metallurgy (57 companies). The estimate for the only sector that can be double-checked (wood and paper) shows that the difference in the estimated shares of processed goods is less than 10 percent ( 88 vs. 84 percent).
} 
Table D1: The shares on processed goods in total output and the index of processing

\begin{tabular}{|c|c|c|c|}
\hline & 'sector & The share of processed goods & The index of processing \\
\hline 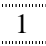 & Electricity & 0.000 & 1.000 \\
\hline 2 & Oil extraction & 0.000 & 1.000 \\
\hline 3 & Oil processing & 1.000 & 0.584 \\
\hline 4 & Gas extraction & 0.000 & 1.000 \\
\hline 5 & Coal and other fuels mining & 0.000 & 1.000 \\
\hline 6 & Iron and steel & 0.897 & 0.657 \\
\hline 7 & Non-ferrous metallurgy & 0.641 & 0.601 \\
\hline 8 & Chemical and petrochemical industry & 0.957 & 0.606 \\
\hline (3) & Machine building and metal processing & 1.000 & 0.364 \\
\hline (10 & Wood and paper & 0.838 & 0.552 \\
\hline 11 & Construction materials & 0.965 & 0.467 \\
\hline 12 & Textile, apparel, and footwear & 1.000 & 0.494 \\
\hline 13 & Food processing & 0.954 & 0.593 \\
\hline (1) & Other industries & 1.000 & 0.410 \\
\hline 15 & Agriculture and forestry & 0.000 & 1.000 \\
\hline
\end{tabular}

Sources: Author's calculations

After the shares of primary production are found, we calculate the index of processing. This concept is to be defined before we can proceed. It deals with the accumulation of value that is added on each stage of processing to the unit value of the primary goods. Mathematically, the problem is to find the variable Index such that

\section{Revenue $\bullet \operatorname{Index} \bullet \mathbf{i}=\operatorname{Cost}^{T} \bullet[\mathbf{I}-$ Share + Share $\bullet$ Index $] \bullet \mathbf{i} \quad[D 1]$}

where $\boldsymbol{C o s t}^{\boldsymbol{T}}$ is the transposed matrix of costs, Revenue, Share, and Index are diagonal matrices of the sectoral revenue, the share of processing, and the index of processing respectively and $i$ is the identity vector. Data on costs and revenues come from the input-output table for 1997 (see Table B1). 
William Davidson Institute Working Paper 428

\section{References}

- Ark, van Bart and Marcel Timmer, PPP and International Productivity Comparisons: Bottlenecks and New Directions, Paper for ILO seminar on Productivity Comparisons, Geneva, Switzerland, January 26, 2001

- Aukutsionek, S. "Barter in Russian Industry", Voprosy Economiki, 2-98: 51-60, February 1998

- CEC (Center for Economic Conjuncture at the Government of the Russian Federation), "Tax Revenue Collected by the Budgetary System of the Russian Federation in January-October 1998", Moscow, (available at http://www.primetass.ru/free/Analitik/Sprav/CEK/Nal/Nal.htm), December 1998

- Clarke, Simon, Trade Unions and non-payment of wages in Russia, manuscript, University of Warwick (available at http://www.warwick.ac.uk/fac/soc/complabstuds/russia/nopay.htm), 1997

- W. M. Corden "The Structure of Tariff System and the Effective protective Rate", Journal of Political Economy, 74, 3: 221-37, June 1966

- Desai, Padma and Todd Idson, Work without wages: Russia's nonpayment crisis, Cambridge and London: MIT Press, 2000

- Gaddy, Clifford G. and Barry W. Ickes, "Russia's Virtual Economy”, Foreign Affairs, September/October: 53-67, 1998a

- Gaddy, Clifford G. and Barry W. Ickes, A Simple Four-Sector Model of Russia's "Virtual” Economy, unpublished paper, The Brookings Institution, May 1998b

- Gaddy, Clifford G. and Barry W. Ickes, Beyond a Bailout: Time to Face Reality About Russia's "Virtual Economy", Unpublished paper (downloadable at http://www.brookings.org/fp/articles/gaddy/gaddick1.htm), June 1998c

- Gaddy, Clifford G. and Barry W. Ickes, "An Accounting Model of the Virtual Economy in Russia”, Post-Soviet Geography and Economics, 40, 2: 79-97, 1999

- General Agreement on Tariffs and Trade (GATT), WTO, Geneva (available at the WTO website http://www.wto.org/english/docs_e/legal_e/gatt47.pdf), July 1986

- $\quad$ GKS (Russian State Committee for Statistics), Russian Statistical Yearbook, Moscow 1996

- GKS, Industry in Russia, Moscow 1998a

- GKS, Finance in Russia, Moscow 1998b

- GKS, Trade in Russia, Moscow 1998c

- GKS, Prices in Russia, Moscow 1998d

- GKS, Russian Statistical Yearbook, Moscow 1998e

- GKS, Labor in Russia, Moscow 1999

- GKS, The System of Input-Output Tables for 1995, Moscow 2000a

- GKS, The National Accounts of Russia 1992-1999, Moscow 2000b 
- Ickes, Barry W. and Richard E. Ericson, A Model of Russia's Virtual Economy, Pennsylvania State University Working Paper, May 2000

- IET, Non-payments, Offsets and Barter, April 2001, downloadable from http://www.iet.ru/

- Ivanenko, Vlad, Effective Tax Rates in Russian Transition, William Davidson Institute working paper \# 378, University of Michigan, 2001 (available at http://papers.ssrn.com/sol3/papers.cfm?abstract_id=272179)

- System of National Accounts 1993 [SNA], joint publication by the Commission of the European Union, IMF, OECD, UN, World Bank; Washington, D.C. 1993

- Treisman, Daniel, "Inter-enterprise Arrears and Barter in the Russian Economy", PostSoviet-Affairs, 16, 3: 225-56, July-Sept. 2000

- United Nations, Handbook of Input-Output Tables Compilation and Analysis, Dept. of Economic and Social Affairs, Statistics Division, Series F \#74, New York 1999

- Woodruff, D., Money Unmade: Barter and the fate of Russian Capitalism, Cornell U.P, 1999 


\section{DAVIDSON INSTITUTE WORKING PAPER SERIES - Most Recent Papers}

The entire Working Paper Series may be downloaded free of charge at: www.wdi.bus.umich.edu

CURRENT AS OF $1 / 21 / 02$

\begin{tabular}{|c|c|c|}
\hline Publication & Authors & Date \\
\hline No. 428: Testing Russia's Virtual Economy & Vlad Ivanenko & Dec. 2001 \\
\hline No. 427: War and the Business Corporation & Eric W. Orts & Dec. 2001 \\
\hline $\begin{array}{l}\text { No. 426: Partial Privatization and Firm Performance: Evidence from } \\
\text { India }\end{array}$ & Nandini Gupta & Dec. 2001 \\
\hline $\begin{array}{l}\text { No. 425: Direct Foreign Investments and Productivity Growth in } \\
\text { Hungarian Firms, 1992-1999 }\end{array}$ & Jérôme Sgard & Nov. 2001 \\
\hline $\begin{array}{l}\text { No. 424: Banking Passivity and Regulatory Failure in Emerging } \\
\text { Markets: Theory and Evidence from the Czech republic. }\end{array}$ & Jan Hanousek and Gerard Roland & July 2001 \\
\hline $\begin{array}{l}\text { No. 423: Conceptions of the Corporation and the Prospects of } \\
\text { Sustainable Peace }\end{array}$ & Jeffrey Nesteruk & Dec. 2001 \\
\hline No. 422: The Role of the Corporation in Fostering Sustainable Peace & Timothy Fort and Cindy Schipani & Nov. 2001 \\
\hline No. 421: Wage Arrears and the Distribution of Earnings in Russia & $\begin{array}{l}\text { Hartmut Lehmann and Jonathan } \\
\text { Wadsworth }\end{array}$ & Dec. 2001 \\
\hline $\begin{array}{l}\text { No. 420: Transferring Collective Knowledge: Collective and } \\
\text { Fragmented Teaching and Learning in the Chinese Auto Industry }\end{array}$ & $\begin{array}{l}\text { Jane Zhou, Jaideep Anand, and } \\
\text { Will Mitchell }\end{array}$ & 2001 \\
\hline $\begin{array}{l}\text { No. 419: Liberalization, Corporate Governance, and the Performance of } \\
\text { Newly Privatized Firms }\end{array}$ & $\begin{array}{l}\text { Narjess Boubakri, Jean-Claude } \\
\text { Cosset, and Omrane Guedhami }\end{array}$ & Dec. 2001 \\
\hline $\begin{array}{l}\text { No. 418: The European Data Privacy Directive and International } \\
\text { Relations }\end{array}$ & Steven R. Salbu & Dec. 2001 \\
\hline $\begin{array}{l}\text { No. 417: Capital Markets and Capital Allocation: Implications for } \\
\text { Economies in Transition }\end{array}$ & $\begin{array}{l}\text { Artyom Durnev, Randall Morck, } \\
\text { and Bernard Yeung }\end{array}$ & Dec. 2001 \\
\hline $\begin{array}{l}\text { No. 416: Forthcoming in: The Journal of Economic Perspectives, "Data } \\
\text { Watch. Research Data from Transition Economies," 16(2) Feb. } 2002 .\end{array}$ & $\begin{array}{l}\text { Randall K. Filer and Jan } \\
\text { Hanousek }\end{array}$ & Dec. 2001 \\
\hline $\begin{array}{l}\text { No. 415: Forthcoming in: The Journal of Economic Perspectives, } \\
\text { "Transition Economies: Performance and Challenges," 16(2) Feb. } 2002 .\end{array}$ & Jan Svejnar & Dec. 2001 \\
\hline $\begin{array}{l}\text { No. 414: Forthcoming in: The Journal of Economic Perspectives, "The } \\
\text { Great Divide and Beyond: Financial Architecture in Transition," 16(2) } \\
\text { Feb. 2002. }\end{array}$ & Erik Berglof and I & Dec. 2001 \\
\hline $\begin{array}{l}\text { No. 413: Forthcoming in: The Journal of Economic Perspectives, "The } \\
\text { Political Economy of Transition," 16(2) Feb. } 2002 .\end{array}$ & Gérard Roland & Dec. 2001 \\
\hline $\begin{array}{l}\text { No. 412: The Response of Consumption in Russian Households to } \\
\text { Economic Shocks }\end{array}$ & Steven Stillman & Oct. 2001 \\
\hline No. 411: Mark-ups in Hungarian Corporate Sector & László Halpern and Gábor Kőrösi & Aug. 2001 \\
\hline No. 410: Economic Development, Legality, and the Transplant Effect & $\begin{array}{l}\text { Daniel Berkowitz, Katarina } \\
\text { Pistor, Jean-Francois Richard }\end{array}$ & Sept. 2001 \\
\hline No. 409: Development Strategy, Viability, and Economic Convergence & Justin Yifu Lin & Oct. 2001 \\
\hline No. 408: Labor Supply, Informal Economy and Russian Transition & Maxim Bouev & May 2001 \\
\hline No. 407: Corporate Governance in China: Then and Now & Cindy Schipani and Liu Junhai & Nov. 2001 \\
\hline No. 406: Entrepreneurship and Post-Socialist Growth & $\begin{array}{l}\text { Daniel Berkowitz and David N. } \\
\text { DeJong }\end{array}$ & Oct. 2001 \\
\hline $\begin{array}{l}\text { No. 405: Forthcoming in: European Economic Review, "Policy Reform } \\
\text { and Growth in Post-Soviet Russia." }\end{array}$ & $\begin{array}{l}\text { Daniel Berkowitz and David N. } \\
\text { DeJong }\end{array}$ & Oct. 2001 \\
\hline $\begin{array}{l}\text { No. 404: Social Policies and Structures: Institutional Frictions and Traps } \\
\text { in the Czech Republic after } 1989\end{array}$ & Jiří Večerník & Nov. 2001 \\
\hline $\begin{array}{l}\text { No. 403: Investment, Efficiency, and Credit Rationing: Evidence from } \\
\text { Hungarian Panel Data }\end{array}$ & Mathilde Maurel & Nov. 2001 \\
\hline $\begin{array}{l}\text { No. 402: Subduing High Inflation in Romania. How to Better Monetary } \\
\text { and Exchange Rate Mechanisms? }\end{array}$ & $\begin{array}{l}\text { Daniel Daianu and Radu } \\
\text { Vranceanu }\end{array}$ & Aug. 2001 \\
\hline
\end{tabular}

